DOI: 10.32089/WBH.PHW.2021.1(275).0002

orcid.org/0000-0001-8838-5651

\author{
LESZEK KANIA
}

Uniwersytet Zielonogórski

\title{
Zadanie bojowe 2 Armii Wojska Polskiego w operacji łużyckiej w świetle źródeł rosyjskich i dotychczasowych ustaleń badaczy. Historia do poprawki
}

\begin{abstract}
The article presents the combat task of the Polish Army grouping, the core of which was the 2nd Polish Army under the command of Gen. Karol Świerczewski in the Lusatian operation (April 16-30, 1945). The findings of Polish and foreign researchers to date incorrectly assigned the Polish group to the role of securing the left wing of the 1st Ukrainian Front in the attack on Dresden. The article verifies these findings on the basis of original sources in the form of orders, which are currently available online in the database of the Ministry of Defense of the Russian Federation.
\end{abstract}

\section{Wprowadzenie}

Dzieje wojenne ludowego Wojska Polskiego (IWP) ${ }^{1}$ na froncie wschodnim z lat 1943-1945 mają swoją literaturę naukową, popularnonaukową, beletrystykę, drukowane materiały źródłowe, filmotekę i memuarystykę. $\mathrm{Z}$ oczywistych względów temat został szybko zagospodarowany w latach PRL przez historyków, którzy nierzadko brali udział w walkach frontowych. Szlak bojowy „kościuszkowców” i 1 Armii Wojska Polskiego (AWP) miał

Stosowana terminologia „Ludowe Wojsko Polskie” rzadko była określana normatywnie. Skrót „LWP” miał odróżnić polskie formacje wojskowe tworzone od 1943 r. przez Związek Sowiecki od Polskich Sił Zbrojnych na Zachodzie podległych rządowi Rzeczypospolitej Polskiej na uchodźstwie. W niniejszym tekście autor stosuje skrót lWP. 
w peerelowskiej historiografii i propagandzie pierwszeństwo przed czynem zbrojnym 2 AWP. Był lepiej znany i rozciągał się na dwa lata wojny, podczas gdy 2 AWP dowodzona przez gen. dyw. Karola Świerczewskiego brała udział w walkach frontowych jedynie przez trzy tygodnie. Mimo to, w latach sześćdziesiątych XX w. ukazały się monografie 2 AWP, trzech dywizji piechoty, kilku brygad i kilkunastu pułków, a na łamach czasopism pogłębione studia, rozprawy, a nawet głosy polemiczne. ${ }^{2}$ Po odzyskaniu wolności badań naukowych w końcu XX w. stanęliśmy przed dylematem, czy

2 Zob. np. Ignacy Blum, „Sprawa 31 pułku piechoty. Tło, przebieg i charakter masowej dezercji żołnierzy 31 pp w 1944 r."' Wojskowy Przegląd Historyczny (WPH) 10, nr 3 (1965); Janusz Bobkowski, $W$ walce $z$ czołgami: $z$ dziejów 9 i 14 brygady artylerii przeciwpancernej 2 armii WP (Warszawa: Wyd. Ministerstwa Obrony Narodowej, 1961); Bobkowski, Kierunek Budziszyn (Warszawa: Wyd. Ministerstwa Obrony Narodowej, 1965); Bobkowski i Czesław Mirowski, Dziewiąta przeciwpancerna. Z dziejów 9 Drezdeńskiej Samodzielnej Brygady Artylerii Przeciwpancernej (Warszawa: Wyd. Ministerstwa Obrony Narodowej, 1972); Stanisław Gać, 7 Dywizja Piechoty: historia 7 Łużyckiej Dywizji Piechoty (Warszawa: Wyd. Ministerstwa Obrony Narodowej, 1970); Edmund Ginalski, Od Żytomierza do Litomiěřic. Zarys dziejów 15 pułku piechoty 1944-1947 (Warszawa: Wyd. Ministerstwa Obrony Narodowej, 1972); Ginalski i Eugeniusz Wysokiński, Dziewiąta drezdeńska. Z dziejów 9 Drezdeńskiej Dywizji Piechoty (1944-1947) (Warszawa: Wyd. Ministerstwa Obrony Narodowej, 1984); Ginalski, 40 pułk artylerii lekkiej. Zarys dziejów 1944-1947 (Warszawa: Wyd. Ministerstwa Obrony Narodowej, 1968); Ginalski, 22 Pułk Artylerii Lekkiej. Zarys dziejów 1944-1947 (Warszawa: Wyd. Ministerstwa Obrony Narodowej, 1974); Mieczysław Juchniewicz, Śladami walk. Z dziejów 37 pułku piechoty (Warszawa: Wyd. Ministerstwa Obrony Narodowej, 1964); Juchniewicz, 36 Łużcki (Warszawa: Wyd. Ministerstwa Obrony Narodowej, 1975); Juchniewicz, Poczta polowa 52160. Z dziejów 35 pułku piechoty (Warszawa: Wyd. Ministerstwa Obrony Narodowej, 1963); Wacław Jurgielewicz, „Rozbudowa Ludowego Wojska Polskiego w II połowie 1944 r.” WPH 8, nr 3/4 (1963); Kazimierz Kaczmarek, W bojach przez Łużyce, red. Emil Jadziak (Warszawa: Wyd. Ministerstwa Obrony Narodowej, 1965); Kaczmarek, „Operacja Łużycka 2 Armii WP, cz. 1, WPH 9, nr 1 (1964) oraz cz. 2 WPH 10, nr 3 (1965); Kaczmarek, Druga Armia Wojska Polskiego (Warszawa: Wyd. Ministerstwa Obrony Narodowej, 1978); Michał Kaseja, Ostatnie uderzenie (Warszawa: Wyd. Ministerstwa Obrony Narodowej, 1969); Kaseja, Razem ze Świerczewskim (Warszawa: Wyd. Ministerstwa Obrony Narodowej, 1968); Kaczmarek, Czwarta pancerna. Z dziejów czwartej brygady pancernej (Warszawa: Wyd. Ministerstwa Obrony Narodowej, 1970); Władysław Katroń, „Udział 16 Dnowskiej Brygady Pancernej w operacji łużyckiej 2 Armii WP, WPH 5, nr 3 (1960); Leon Lubecki, Na potudnie od Berlina. Z walk 26 pp (Warszawa: Wyd. Ministerstwa Obrony Narodowej, 1960); Zbigniew Raźnikiewicz, Formowanie i przygotowanie do działań bojowych oraz udział wojsk pancerno-motorowych w operacji łużckiej (Warszawa: Wyd. Ministerstwa Obrony Narodowej, 1970); Stanisław Rzepski, 8 Dywizja Piechoty. Z dziejów 8 Drezdeńskiej Dywizji Piechoty im. Bartosza Głowackiego (Warszawa: Wyd. Ministerstwa Obrony Narodowej, 1970); Józef Sankowski, „Działania 2 Armii Polskiej na rzeką Nysą,” Bellona 2, z. 3/4 (1946); Saturnina Wadecka, Budziszyn - kwiecień 1945 (Warszawa: Wyd. Ministerstwa Obrony Narodowej, 1970); Włodzimierz Wołoszyn, Pod Budziszynem i Dreznem. Z dziejów 30 pułku piechoty (Warszawa: Wyd. Ministerstwa Obrony Narodowej, 1963) i inne. Historii wojennej 2 AWP i operacji łużyckiej został poświęcony trzeci tom edycji materiałów źródłowych Organizacja i działania bojowe Ludowego Wojska Polskiego w latach 1943-1945. Szkolenie, przegrupowania i działania bojowe 2 Armii WP, red. Stanisław Stąpor (Warszawa: Wyd. Ministerstwa Obrony Narodowej, 1965). 
nie powinniśmy przebiegu walk z udziałem oddziałów lWP zweryfikować i w razie potrzeby napisać od nowa. Te późniejsze prace powstały bez ingerencji cenzora, narzuconej badaczom polityki historycznej i krępujących ich więzów ideologicznych. Dlatego ukazują prawdziwe tło wydarzeń, sylwetki dowódców, dominującą rolę aparatu polityczno-wychowawczego, sądownictwa wojskowego i terror aparatu bezpieczeństwa bez żadnego retuszu. ${ }^{3}$

W badaniach nad dziejami 2 AWP obserwujemy pewien zastój. Uczeni nowego pokolenia nie uznają tej problematyki za atrakcyjną prawdopodobnie z tego względu, że „wszystko zostało już napisane”. Tymczasem na tym polu badawczym jest jeszcze wiele do zrobienia. Błędy i przemilczenia popełnione przed laty są na tyle istotne, że wypaczają generalną ocenę wysiłku wojennego ludowego Wojska Polskiego w operacji łużyckiej. W prezentowanym szkicu koncentruję się na przedstawieniu faktycznego zadania bojowego 2 AWP na drezdeńskim kierunku operacyjnym. Błędy popełnione przez peerelowskich historyków uruchomiły wiele pochopnych opinii w przedmiocie oceny wysiłku wojennego oddziałów lWP. Błędy te, jeżeli mamy do czynienia tylko z błędami, również wykorzystywane są przez współczesnych autorów rosyjskich, którzy stali się wiarygodnym źródłem wiedzy dla polskich czytelników. W tym krytycznym spojrzeniu na dorobek badaczy wysiłku wojennego żołnierzy 2 AWP w latach 1945-1990 bazowałem na literaturze, memuarach i oryginalnych źródłach w postaci rozkazów, raportów, komunikatów i innych dokumentów wytworzonych w ostatnim roku wojny przez sztab 1 Frontu Ukraińskiego (FU), dowództwa związków operacyjnych i taktycznych Armii Czerwonej, które udostępnia portal Centralnego Archiwum Ministerstwa Obrony Federacji Rosyjskiej. ${ }^{4}$

\footnotetext{
3 Zob. np. Henryk Garbowski, W zaułkach frontu pod Budziszynem (Pruszków: Ofic. Wyd. „Ajaks”, 2003); Czesław Grzelak, Henryk Stańczyk i Stefan Zwoliński, Bez możliwości wyboru. Wojsko Polskie na froncie wschodnim 1943-1945 (Warszawa: Bellona, 1993); Paweł Jaroniec, „Obraz żołnierzy Armii Czerwonej we wspomnieniach kombatantów «ludowego» Wojska Polskiego na froncie wschodnim w latach 1943-1945 publikowanych w polskiej prasie codziennej w latach 70. XX wieku. Przyczynek do zagadnienia," Studia z Dziejów Wojskowości 5, (2016); Leszek Kania, „Sądy wojenne w Ludowym Wojsku Polskim (19431945)," Miscellanea Historico-Iuridica 15, z. 1 (2015); Edward Kospath-Pawłowski, Wojsko Polskie na Wschodzie 1943-1945 (Pruszków: Ofic. Wyd. „Ajaks”, 1993); Franciszek Kusiak, Generał Karol Świerczewski Walter - życie i po życiu 1887-1947-2017 (Wrocław: Wyd. Eurosystem, 2017); Edward Nalepa, Oficerowie Armii Radzieckiej w Wojsku Polskim 1943-1968 (Warszawa: Bellona, Wojskowy Instytut Historyczny, 1995); Stańczyk i Zwoliński, Wojsko Berlinga i Żymierskiego 1943-1945 (Warszawa: Ofic. Wyd. „Rytm”, 2015); Władysław Tkaczew, Organa Informacji Wojska Polskiego 1943-1956. Kontrwywiad wojskowy (Warszawa: Bellona, 2007); Andrzej Wesołowski, W cieniu wojny i polityki. Sadownictwo Wojska Polskiego na froncie wschodnim w latach 1943-1945 (Toruń: Wyd. Adam Marszałek, 2003) i inne.
}

4 https://pamyat-naroda.ru/documents/, dostęp styczeń 1, 2021. 


\section{Stan badań}

Pierwsze lata po wojnie nie przyniosły masowego, spektakularnego wysypu publikacji o epopei wojennej 2 AWP poza szkicami uczestników wydarzeń i rozrachunkami we własnym gronie. Szef sztabu 2 AWP, gen. dyw. Józef Sankowski, tuż po zakończeniu wojny próbował na łamach Bellony wybielać dowództwo armii, ale nie był to właściwy czas na tego rodzaju retrospekcje. Po wojnie kozłem ofiarnym porażek na przedpolach Drezna uczyniono dowódcę 9 Dywizji Piechoty (DP) płk. Aleksandra Laskiego. Postawiono go przed wojskową komisją specjalną, obarczono cudzymi błędami i odesłano z powrotem do Związku Sowieckiego. Na publikacje bazujące na relacjach i dokumentach źródłowych trzeba było czekać do popaździernikowej odwilży. Autorzy książek, często weterani walk na Łużycach (Mieczysław Juchniewicz, Janusz Bobkowski, Leon Lubecki, Stanisław Gać, Eugeniusz Ginalski, Włodzimierz Wołoszyn i in.), wydawali drukiem monografie kolejnych pułków. Z braku dostępu do sowieckich źródeł nie zajmowali się problemami strategicznymi. Okres popaździernikowej odwilży w polityce i kulturze trwał w państwach socjalistycznych kilka lat, co pozwoliło autorom przemycić wiele ciekawych treści. ${ }^{5}$

Jednym z pierwszych badaczy, który wprowadził pojęcie „pomocniczego kierunku" drezdeńskiego i ograniczył rolę 2 AWP do zabezpieczenia lewego skrzydła $1 \mathrm{FU}$, był płk dypl. Marek Klibański. ${ }^{6}$ Po nim pogląd ten powtórzył mjr dypl. Stanisław Łaniewski i inni autorzy. ${ }^{7} \mathrm{~W}$ tych publikacjach widzimy echa artykułu gen. Sankowskiego z 1946 r., w którym narzucił obowiązującą do dziś narrację na temat zadań 2 AWP i przebiegu walk na Łużycach. Po serii studiów i rozpraw naukowych, które ukazały się w obiegu zamkniętym na uczelniach wojskowych, nadszedł czas na publikacje otwarte. Działania 2 AWP doczekały się analiz na łamach czasopism krajowych. Wiedli w nich prym głównie historycy i specjaliści nauk wojskowych. W tym gronie szybko zyskał renomę Kazimierz Kaczmarek, autor kilku prac poświęconych epopei „wojska Świerczewskiego”, w tym monografii 2 AWP. W latach 1964-1965 opublikował dwuczęściowe studium poświęcone udziałowi lWP w operacji łużyckiej. Zawarte tam ustalenia Kaczmarek powielił

\footnotetext{
5 W Związku Sowieckim opublikowano w tym czasie wiele materiałów o szkodliwości kultu jednostki i nakręcono kilka filmów wojennych o charakterze rozliczeniowym będących ekranizacją prozy Konstantina Simonowa i innych autorów, które ukazały krytyczne momenty wojny z Niemcami („Żywi i martwi”, „Nikt nie rodzi się żołnierzem”, „Ojciec żołnierza”, „Lecą żurawie”, „Oni walczyli za ojczyznę”).

6 Marek Klibański, „Działania bojowe 2 Dywizji Artylerii w operacji łużyckiej 2 Armii WP,' WPH 6, nr 1 (1961), 55.

7 Stanisław Łaniewski, „Udział 7 Dywizji Piechoty w bitwie budziszyńskiej 2 Armii WP 20.04.-4.05.1945 r." WPH 6, nr 3 (1961), 15.
} 
w monografii 2 AWP. Mimo poważnego dorobku naukowego i wysokich not od współczesnych Kaczmarek popełnił poważny błąd, który powtórzyli inni badacze, zaś wielu historyków replikuje go współcześnie bez refleksji i weryfikacji w dokumentach źródłowych. Spójrzmy zatem, jak Kaczmarek i historycy z minionej epoki przedstawili zadania 2 AWP i jej sąsiadów w operacji łużyckiej.

Analiza pierwszej części jego opracowania zamieszczonego na łamach Wojskowego Przeglądu Historycznego w 1964 r. sugeruje, że autor mógł nie mieć dostępu do źródeł. Ale to nieprawda. Pierwsza część tego studium zatytułowana „Operacja łużycka 2 Armii WP” zawiera przedstawienie zadań polskiego zgrupowania uderzeniowego i sąsiadujących z nim związków operacyjnych Armii Czerwonej na podstawie dyrektywy dowódcy 1 Frontu Ukraińskiego nr 00211/op. z 8 kwietnia 1945 r. Wedle ustaleń Kaczmarka 5 Armia Gwardii (AGw.) gen. Aleksieja Żadowa, działająca na prawym skrzydle 2 AWP, po sforsowaniu Nysy Łużyckiej miała przełamać niemiecką obronę na odcinku od Żarek do Mużakowa i nacierać na osi SprembergTorgau $\mathrm{z}$ ominięciem $\mathrm{z}$ lewej strony kompleksu lasów mużakowskich. Słowem, 2 AWP nie miała większego pożytku z obecności na prawej flance 5 AGw. Tymczasem lewoskrzydłowy 34 Korpus Strzelecki (KS) tej armii z 4 Korpusem Pancernym Gwardii (KPanc. Gw.) otrzymały zadanie wyprowadzenia natarcia na Drezno po osi Weißwasser-Wittchenau-Kamenz.

O zadaniu lewoskrzydłowej 52 Armii (A) gen. Konstanina Korotiejewa badacz ten pisze zaś następująco: „Wojska prawego skrzydła tej armii miały nacierać w kierunku Budziszyna [...] natomiast wojska działające na lewym skrzydle winne pozostać w obronie wzdłuż Sudetów. Dyrektywa nakazywała, by na lewym skrzydle 52 armia przeszła do twardej obrony".

Zobaczmy teraz, jak Kaczmarek przedstawił zadanie postawione 2 AWP w dyrektywie nr 00211/op.: „2 armia Wojska Polskiego i 52 armia radziecka weszły w skład zgrupowania pomocniczego 1 Frontu Ukraińskiego. Bezpośrednim zadaniem tego zgrupowania było prowadzenie natarcia w kierunku Drezna i zabezpieczenie od południa odsłoniętego skrzydła zgrupowania uderzeniowego frontu obchodzącego Berlin $\mathrm{z}$ kierunku południowo-zachodniego. $Z$ analizy zadania obydwu armii wynika, iż głównym ich celem nie było jednak opanowanie Drezna; wychodzono z założenia, że jeśli będzie zdobyty Berlin, to Drezno samo na pewno padnie".

Identyczny passus znalazł się we wstępie tego autora do przywołanego wyżej trzeciego tomu zbioru dokumentów źródłowych pt. Organizacja $i$ działania bojowe ludowego Wojska Polskiego w latach 1943-1945. ${ }^{10}$

\footnotetext{
8 Kaczmarek, „Operacja łużycka 2 Armii WP, 4-5.

9 Ibid., 5.

10 Stąpor, Organizacja i działania, 3:17-18.
} 
W monografii 2 AWP, która ukazała się w 1968 r., Kaczmarek napisał podobnie o zadaniu postawionym $\mathrm{w}$ dyrektywie nr 00211/op. 2 AWP i $52 \mathrm{~A}$, które nie wiedzieć czemu badacz ten złączył w jedno zgrupowanie bojowe: „Zgrupowanie to, którego główne siły stanowiła nasza armia, winno jednocześnie odciąć odwody niemieckie ześrodkowane w Czechosłowacji, a tym samym osłonić lewe skrzydło głównego zgrupowania 1 Frontu Ukraińskiego oraz tyły wojsk radzieckich walczących pod Berlinem. Było to podstawowe zadanie zgrupowania zabezpieczającego, a jego wykonaniu powinny być podporządkowane wszystkie poczynania operacyjne naszej armii". ${ }^{11}$

Akapit niżej badacz opisał, jak dyrektywa nr 00211/op. odniosła się do zadań bojowych $78 \mathrm{KS}$ i $48 \mathrm{KS}$ z 52 A. Kaczmarek nazwał te korpusy „Zgrupowaniem wiążącym” i stwierdził, że pięć dywizji strzeleckich (DS): 116 DS i 213 DS, 373 DS, 31 DS i 214 DS miało związać wojska nieprzyjaciela wzdłuż Sudetów i „w jakieś mierze wzmocnić blokadę Wrocławia”. ${ }^{12}$ To także nieprawda. $48 \mathrm{KS}$ w przeddzień ofensywy miał tylko dwie dywizje strzeleckie - 116 DS i 213 DS, gdyż trzecia (294 DS) w tym czasie walczyła o Wrocław. Marszałek Iwan Koniew nakazał zresztą powrót 294 DS płk. Gieorgija Korolenki do macierzystego korpusu, z Wrocławia nad Nysę Łużycką na cztery dni przed ofensywą i dywizja ta wzięła udział w bitwie na Łużycach, a nie na ulicach Wrocławia. Skąd myśl, że to mityczne „zgrupowanie wiążące” miałoby wspomóc blokadę Wrocławia, skoro zabierano stamtąd nie tylko stutysięczne zgrupowanie Wojska Polskiego, ale także 294 DS? Ustalenia Kaczmarka, w których przedstawił zadania bojowe 2 AWP i 52 A na drezdeńskim kierunku operacyjnym, nie miało podstaw w treści dyrektywy nr 00211/op.

Za Kaczmarkiem poszli inni autorzy, którzy przypisali Świerczewskiemu i Korotiejewowi zadanie zablokowania od południa wojsk feldmarszałka Ferdinanda Schörnera, który rzekomo maszerował na odsiecz obrońcom Berlina. Takie myślenie pokutuje do dziś nie tylko na kartach prac naukowych, ale w kinematografii, literaturze i memuarystyce. Karl Bahm w książce poświęconej bitwie o Berlin stwierdził, że „Grupa Görlitz”, jak nazwał zgrupowanie wojsk Schörnera, była tylko o krok od przełamania okrążenia, w którym znalazła się 9 A niemiecka. ${ }^{13}$ Bahm puścił wodze fantazji, gdyż nie przestudiował losów słynnego kotła pod Halbe. Nie przekonał bowiem czytelników, w jaki sposób trzy dywizje "Grupy Görlitz” i kilka grup bojowych liczących ogółem ok. 30 tys. ludzi miało się przebić przez trzy armie ogólnowojskowe i trzy korpusy pancerno-motorowe, aby wyrwać z kotła 9 A otoczoną przez cztery armie sowieckie? Pytanie, czy feldmarszałek

\footnotetext{
11 Kaczmarek, Druga, 305.

12 Ibid.

13 Karl Bahm, Berlin 1945, tłum. Michał Kompanowski (Warszawa: Bellona, 2015), 185.
} 
Schörner w ogóle myślał o odsieczy Berlina? Nic na to nie wskazuje. Z relacji żołnierzy niemieckiej 4 Armii Pancernej (APanc.), którzy walczyli pod Dreznem, wynika wprost, że cierpieli na dotkliwy deficyt amunicji i paliwa. Powtarzał się zatem dramat znany $z$ ofensywy w Ardenach. Celem natarcia niemieckich oddziałów pancernych z rejonu Görlitz w kierunku Königswartha był tamtejszy armijny magazyn amunicyjny, który zdobyli żołnierze 2 AWP. Podoficer z Dywizji Grenadierów Pancernych „Brandenburg” wspominał po latach, że $\mathrm{z}$ powodu braku paliwa napełniano baki czołgów do połowy, a gdy zużył jednego dnia 3 tys. pocisków do karabinu maszynowego w swoim czołgu, to otrzymał naganę za rozrzutność. ${ }^{14}$ Tylko Bahm dostrzegł zagrożenie dla zgrupowania dwóch frontów sowieckich pod Berlinem, liczących łącznie $1,5 \mathrm{mln}$ żołnierzy ze strony odtworzonych $\mathrm{z}$ trudem trzech odwodowych dywizji „Grupy Görlitz”, które nie miały paliwa i amunicji. Jak wiemy, Schörner mimo początkowych sukcesów nie przebił się przez linię bojową 2 AWP i 52 A. Jednym słowem, nawet nie doszedł do pasa natarcia $5 \mathrm{AGw}$. i $4 \mathrm{KPanc}$. Gw. Po cóż zatem tak śmiałe i efektowne teorie? Bahm nie chce przyjąć do wiadomości, że oddziały Korpusu Pancernego „Grossdeutschland”, które zostały rozbite przez dywizje 5 AGw. i brygady czołgów 4 KPanc. Gw. w rejonie Weißwasser, przebijały się na południe do Schörnera, a nie na północ, pod Cottbus. Na polach Saksonii i Łużyc nikt realnie nie myślał o odsieczy Berlina.

Pogląd forsowany przez Kaczmarka, jakoby marsz. Koniew, dowódca 1 FU, powierzył 2 AWP i 52 A zadanie zabezpieczenia lewego skrzydła wojsk nacierających na Drezno, powtórzyli w swoich publikacjach inni autorzy. Spójrzmy na niektóre nazwiska, gdyż byli to wytrawni badacze i oficerowie dyplomowani z dorobkiem naukowym. Zdzisław Stąpor literalne powtórzył za Kaczmarkiem zadanie bojowe 2 AWP w operacji łużyckiej. ${ }^{15}$ Błędnie powielali rzekome zadanie 2 AWP autorzy prac naukowych i popularnonaukowych w latach sześćdziesiątych i siedemdziesiątych XX w., jak Janusz Bobkowski, Czesław Mirowski, Leon Lubecki, Mieczysław Juchniewicz, Eugeniusz Ginalski, Eugeniusz Wysokiński, Włodzimierz Wołoszyn, Stanisław Rzepski, Stanisław Gać i in. ${ }^{16}$

Po obaleniu komunizmu nowe pokolenie badaczy podtrzymało poglądy Kaczmarka i peerelowskich autorów na temat zadania bojowego 2 AWP

14 Eduard Bodenmüller, Con i Panther della Brandenburg. Febbraio-Maggio 1945 (Genova: Wyd. Soldiershop Publishing, 2015), 32-34.

15 Zdzisław Stąpor, Berlin 1945 (Warszawa: Bellona, 2015), 48 i 58.

16 Bobkowski i Mirowski, Dziewiąta Przeciwpancerna, 55; Ginalski, 22 Pułk, 134; Ginalski, Od Żytomierza, 103; Wołoszyn, Pod Budziszynem, 158; Lubecki, Na południe od Berlina, 176; Ginalski i Wysokiński, Dziewiąta Drezdeńska, 134; Juchniewicz, 36 Łużycki, 57; Gać, 7 Dywizja, 134; Rzepski, 8 Dywizja, 135. 
w operacji łużyckiej. Jak mantrę powielają plotki o ignorancji Świerczewskiego i fatalnych błędach w dowodzeniu armią na Łużycach. Henryk Stańczyk i Stefan Zwoliński w wartościowej książce, w której podjęli się trudu odkłamania historii ludowego Wojska Polskiego, piszą następująco: „Generał Świerczewski zupełnie nie orientował się w niebezpieczeństwie, jakie zagrażało armii z lewego skrzydła. 22 kwietnia rano rozkazał nadal nacierać na Drezno trzem dywizjom piechoty i jednocześnie zaangażował na tym kierunku 1 Korpus Pancerny". ${ }^{17}$

Autorzy ci podali również bez sprawdzenia źródeł, że Świerczewski przez ignorancję wygubił swoją 248 DS w pierwszych miesiącach wojny niemiecko-sowieckiej i nie byli w tym odosobnieni. ${ }^{18} \mathrm{Z}$ takim poglądem nie zgodził się Franciszek Kusiak, który w biografii generała „Waltera” wziął go w obronę za klęskę jego dywizji pod Wiaźmą i zaoponował przed dorabianiem łatki ignoranta wojskowego. ${ }^{19}$ Badacz ten zaproponował całkiem odmienne spojrzenie na dowodzenie armią pod Budziszynem, choć w pracy biograficznej chciałoby się uzyskać nieco więcej niż dwa zdania na temat zadania 2 AWP w operacji łużyckiej. ${ }^{20}$

Obecnie w publikacjach poświęconych 2 AWP nadal powiela się pogląd $\mathrm{z}$ minionej epoki, że krwawe straty poniesione przez polskie zgrupowanie bojowe na Łużycach były wynikiem „uporczywego" dążenia Świerczewskiego do zdobycia Drezna. ${ }^{21}$ Jednym z nielicznych autorów, który podjął się obrony dowództwa 2 AWP i wskazał marszałka Koniewa jako winowajcę spowodowania chaosu na Łużycach, był Piotr Różański. ${ }^{22}$ Niestety, autor ten nie poparł szkicu o szlaku bojowym 2 Dywizji Artylerii aparatem naukowym. Postaram się wykazać, że poglądy polskich badaczy na zadanie bojowe 2 AWP w operacji łużyckiej i większość opinii o stylu dowodzenia związkiem operacyjnym przez Świerczewskiego pod Dreznem były obiektem manipulacji lub obarczone są błędami.

W myśl dyrektywy dowódcy 1 FU do operacji berlińskiej nr 00211/op. z 8 kwietnia 1945 r. na polskim zgrupowaniu bojowym (2 AWP licząca

\footnotetext{
17 Stańczyk i Zwoliński, Wojsko Berlinga i Żymierskiego, 327. Zob. także: E. Łańcucki, „Od Nysy Łużyckiej po Drezno i Pragę. 1 Korpus Pancerny w operacjach budziszyńskiej i praskiej, kwiecień-maj 1945 r.," Nowy Głos Kawalerii Pancernej, 36 (2000): 30 i n.

18 Grzelak, Stańczyk i Zwoliński, Bez możliwości wyboru, 199; Mariusz Patelski, „Karol Świerczewski «Walter» - Komunista i generał," Zeszyty Naukowe Uniwersytetu Opolskiego 36, z. 36 (1996): 79; Stańczyk i Zwoliński, Wojsko Berlinga i Żymierskiego, 323.

19 Kusiak, Generat, 19.

20 Ibid., 54 i n.

21 Jacek Domański, Budziszyn 1945 (Warszawa: Wyd. „Militaria”, 2009), 80.

22 Piotr Różański, „Powstanie, organizacja oraz szlak bojowy 2 Łużyckiej Dywizji Artylerii,” Wojsko i Technika, listopad-grudzień, nr 6 spec. (2018): 68-79.
} 
pięć DP i 16 Brygadę Pancerną /BPanc./, 1 KPanc. WP, dwie dywizje artylerii, pełnoetatowe dwie brygady przeciwpancerne i jednostki wsparcia) wcale nie ciążył obowiązek osłony lewego skrzydła wojsk nacierających na Drezno. Z kolei duże straty, które poniosły jego oddziały, i kwestionowane przez badaczy decyzje dowódcy 2 AWP w dowodzeniu wojskami były wynikiem rażących błędów popełnionych przez dowództwo $1 \mathrm{FU}$. W szczególności poważnym błędem była decyzja szefa sztabu $1 \mathrm{FU}$, gen. Iwana Pietrowa, który w nocy z 16 na 17 kwietnia 1945 r. w istotny sposób zmodyfikował plan operacji łużyckiej. Aby to czytelnie wykazać, muszę odwołać się do źródła, tj. do dyrektywy dowódcy 1 FU marszałka Koniewa nr 00211/op. datowanej na 8 kwietnia 1945 r. Dyrektywa ta była bowiem rozkazem bojowym adresowanym do dowódców związków operacyjnych w operacji berlińskiej. W monografii 2 AWP Kaczmarek powołał się tylko na wyciąg z dyrektywy, który został zamieszczony w zbiorze drukowanych dokumentów źródłowych poświęconych organizacji i działaniom bojowym lWP. ${ }^{23}$ I tutaj dochodzimy do sedna problemu. Jest dla mnie tajemnicą, dlaczego w liczącym 1100 stron opasłym tomie dokumentów źródłowych redaktorzy poskąpili miejsca na skopiowanie w całości dyrektywy marszałka Iwana Koniewa nr 00211/op do ofensywy na Niemcy? Wszak to najważniejszy dokument w trzecim tomie edycji źródeł. Zaoszczędzenie kilku linijek tekstu przyniosło ten efekt, że czytelnik nie dowiedział się przez pół wieku, że zadanie osłony lewego skrzydła zgrupowania bojowego wojsk 1 FU w natarciu na Drezno marszałek Koniew nie powierzył ani dowódcy 2 AWP, ani też dowódcy 52 A. Treść dyrektywy nr 00211/op. marszałka Iwana Koniewa do operacji berlińskiej była w posiadaniu naszych badaczy z Wojskowego Instytutu Historycznego (WIH). Wynika to wprost z informacji zawartych w trzecim tomie zbioru dokumentów źródłowych i z monografii Kaczmarka o szlaku bojowym 2 AWP. W tej ostatniej pracy Kaczmarek powołał się na znajomość treści dyrektywy nr 00211/op. z 8 kwietnia 1945 r. i prawidłowo przytoczył sygnatury z Centralnego Archiwum Ministerstwa Obrony ZSRS. A właśnie w WIH pełnił w tych latach czynną służbę płk dr Kazimierz Kaczmarek, autor kilkunastu publikacji naukowych na temat planowania i przebiegu operacji łużyckiej ze szczególnym uwzględnieniem roli ludowego Wojska Polskiego. Co ciekawe, Kaczmarek był również autorem przedmowy do trzeciego tomu opisanego wyżej zbioru dokumentów źródłowych, w którym znalazł się wyciąg z dyrektywy nr 00211/ op. Kaczmarek jako badacz operacji łużyckiej znał ten dokument w całości. ${ }^{24}$ Gdyby w trzecim tomie zbioru dokumentów źródłowych redaktorzy

23 Stąpor, Organizacja i działania, 3:203-205. Kaczmarek powołał się tylko na wyciąg z dyrektywy nr 00211/op. Zob. Kaczmarek, Druga, 305.

24 Oryginał dyrektywy nr 00211/op. znajdował się w Centralnym Archiwum Wojskowym, zob. Centralne Archiwum Wojskowe Wojskowego Biura Historycznego (dalej: CAW-WBH), 
zamieścili cały tekst dyrektywy marszałka Koniewa nr 00211/op., to jego przedmowa nie miałaby sensu. Kaczmarek powtórzył we wstępie do tomu trzeciego, że zadaniem 2 AWP było ubezpieczenie lewego skrzydła wojsk $1 \mathrm{FU}$, a nie natarcie na Drezno. Historycy z WIH decydowali w tym czasie, które rozkazy i zarządzenia bojowe w całości lub w części zostaną włączone lub wyeliminowane ze zbioru drukowanych dokumentów źródłowych. Dla przykładu, jeśli porównamy rozkaz dowódcy 2 AWP skierowany do dowódcy 8 DP z 27 kwietnia 1945 r., przedstawiony jako dokument nr 598 z tomu trzeciego, $\mathrm{z}$ oryginałem tego rozkazu $\mathrm{z}$ teczki osobowej Karola Świerczewskiego zdeponowanej w stołecznym Archiwum Akt Nowych, to znajdziemy zasadniczą różnicę $\mathrm{w}$ tekście. ${ }^{25} \mathrm{Z}$ tomu trzeciego wyłączono adresowany do płk. Józefa Grażewicza obraźliwy akapit o jego niedołęstwie i braku zdecydowania. Przedstawienie wyciągu, a nie pełnej treści dyrektywy nr 00211/ op. do natarcia przez Nysę Łużycką miało znacznie ważniejsze konsekwencje. Peerelowscy badacze uzyskali możliwość opisania operacji łużyckiej w sposób tendencyjny i niezgodny $\mathrm{z}$ faktami. Mam pełne podstawy sądzić, że to nie był wypadek przy pracy.

\section{Dyrektywa dowódcy 1 Frontu Ukraińskiego nr 00211/op. z 8 kwietnia 1945 r.}

Wojska $1 \mathrm{FU}$ w przededniu operacji berlińskiej zajmowały front o długości około 360 km, który przebiegał od wsi Sękowice pod Gubinem wzdłuż brzegu Odry i Nysy Łużyckiej przez Lubań Śląski, Jawor, Strzelin, Prudnik, Nysę do Krnova na Morawach. Północna granica pasa natarcia wojsk $1 \mathrm{FU}$ zaczynała się mniej więcej na północ od Cottbus i biegła przez Jüterborg do rejonu Magdeburga, czyli miasta położonego najdalej na zachód nad Łabą. Jeśliby przyłożyć linijkę do mapy i wykreślić linię poziomą, która wyznaczała granicę pasa natarcia wojsk $1 \mathrm{FU}$, to od tej linii do południowych przedmieść Berlina było co najmniej $60 \mathrm{~km}$. Podstawą prac planistycznych dla dowódcy 2 AWP i podległych mu oddziałów była wspomniana dyrektywa nr 00211/op. z 8 kwietnia 1945 r. o przejściu do ofensywy. ${ }^{26}$ Termin rozpoczęcia natarcia wyznaczono na 16 kwietnia 1945 r., godz. 6:15 czasu moskiewskiego. Wedle dyrektywy

Dowództwo 2 Armii Wojska Polskiego, III.5.27, 149-151.

25 Zob. Organizacja i działania, 3:679 oraz Archiwum Akt Nowych w Warszawie, Zbiór akt osobowych działaczy ruchu robotniczego - akta Karola Świerczewskiego, 2/1582/0/-/5916, Rozkaz do dowódcy 8 DP, m.p., 27 IV 1945 r., 5.

26 Центральный Архив Министерства Обороны Российской Федерации (dalej: ЦАМО), Фонд 236: 1 Украинский фронт (dalej: f. 236), Опись (dalej: op.) 2673, Дело (dalej: d.) 2583, Журнал боевых действий 1 Украинского фронта (dalej: Dziennik działań bojowych $1 \mathrm{FU}$ ) 01.04.1945-30.04.1945, b.m., b.d., 63-68, dostęp grudzień 15, 2020, https:// pamyat-naroda.ru/documents/view/?id=10204228\&backurl=\%20q\%5C1\%20\%\%20 


\section{Schemat 1. Plan operacji łużyckiej 2 AWP na 16 kwietnia 1945 r.}

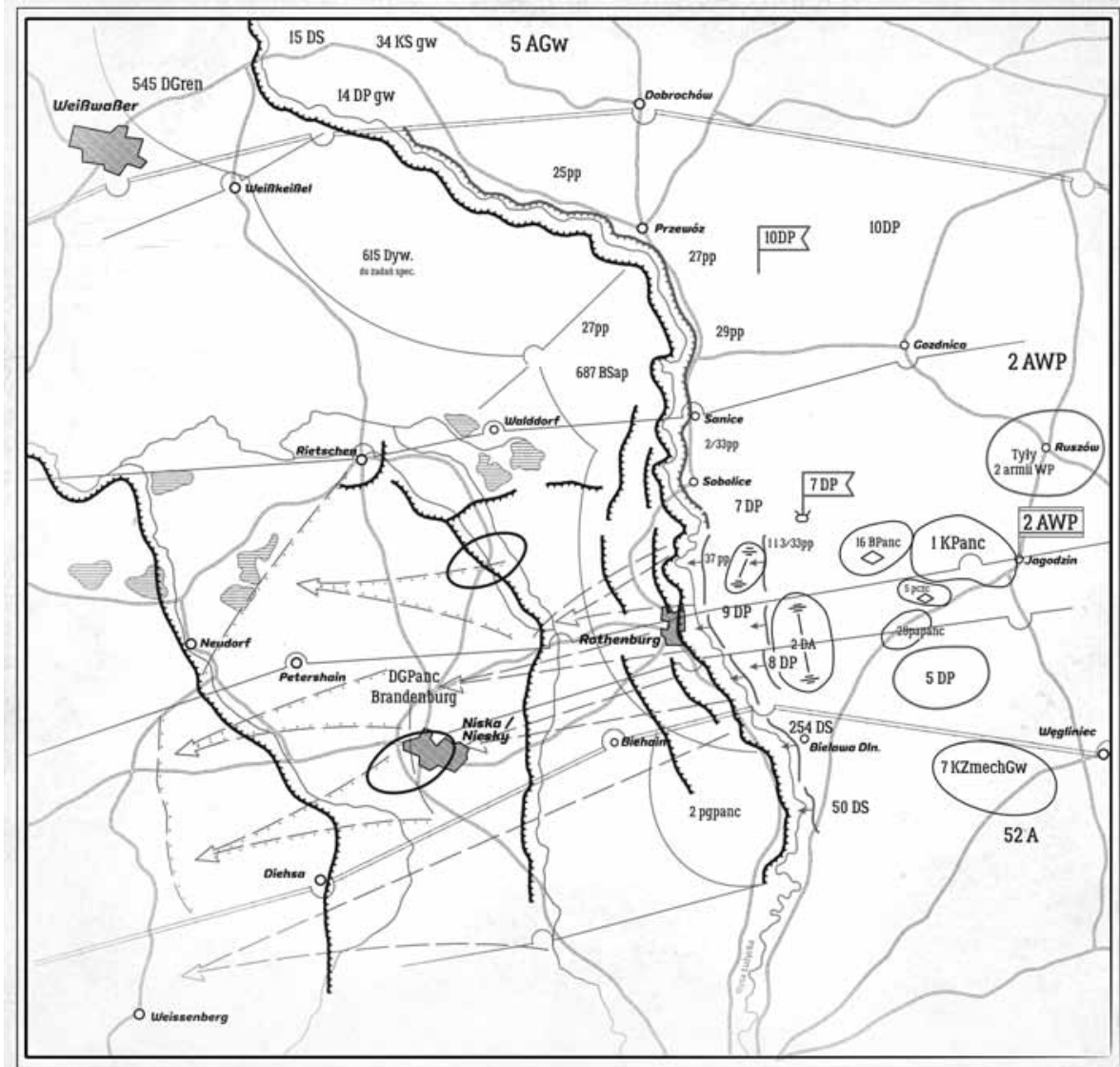

Plan operacji łużyckiej 2 Armii WP na dzień 16 kwietnia $1945 \mathrm{r}$.

Źródło: oprac. własne autora

nr 0211/op., którą przygotował gen. Iwan Pietrow i oficerowie Zarządu Operacyjnego, wojska frontu miały wyprowadzić uderzenie w kierunku na Szpremberg-Belzig $\mathrm{w}$ celu rozgromienia zgrupowania wojsk nieprzyjaciela $\mathrm{w}$ rejonie Cottbus i na południe od Berlina, aby w 10-12 dniu ofensywy osiągnąć rubież Beelitz-Wittenberga i dojść w tym rejonie do Łaby, a następnie wzdłuż rzeki do Drezna, mając na względzie wsparcie wojsk 1 Frontu Białoruskiego $(1 \mathrm{FB})$ w natarciu na Berlin. W pasie natarcia $1 \mathrm{FU}$ na odcinku od Bad Muskau (Mużakowa) do Penzig (Pieńska) miała wejść do akcji 5 AGw. wraz z 4 KPanc. Gw., 2 AWP z 1 KPanc. WP, z wielkimi jednostkami artylerii i oddziałami 
towarzyszącymi, 52 A z 7 Korpusem Zmechanizowanym Gwardii (KZmech. Gw.) i 1 Korpus Kawalerii Gwardii (1 KKGw.), który w ostatniej chwili skierowano $\mathrm{z}$ odwodu dowódcy $1 \mathrm{FU}$. W tym czasie pozostałe armie i jednostki 1 FU zajmujące pozycje od Przedgórza Sudeckiego do Bramy Morawskiej miały przejść do obrony.

Dyrektywa nr 00211/op. określiła zróżnicowaną głębokość zadań dla poszczególnych związków operacyjnych frontu. Różnice wynikały z wyjściowego położenia armii i grup szybkich względem linii Łaby. Głębokość zadania przewidzianego dla 2 AWP wynosiła około $90 \mathrm{~km}$, a dla $52 \mathrm{~A}$ ok. $65 \mathrm{~km}$. Zdobycie Drezna i szybkie dotarcie do Łaby obok zajęcia Berlina było jednym z priorytetów Józefa Stalina. W myśl dyrektywy nr 00211/op. to nie stolica III Rzeszy była głównym celem natarcia wojsk $1 \mathrm{FU}$, lecz Wittenberga na północy i Drezno na południu. Ewentualny marsz armii pancernych, którymi dysponował dowódca $1 \mathrm{FU}$, na Berlin założono jako ewentualność. ${ }^{27}$ Marszałek Koniew chciał jak najszybciej dotrzeć do Łaby, żeby powitać tam Amerykanów. Stalin obawiał się, że alianci nie zatrzymają się na zachodnim brzegu tej rzeki. W rzeczywistości to Amerykanie czekali nad Łabą na wojska sowieckie, a nie na odwrót. To, że dwie armie pancerne Koniewa skręciły ostro na północ i zaatakowały Berlin z południa, było konsekwencją ogromnych problemów Georgija Żukowa w czołowym natarciu przez Wzgórza Seelowskie.

Wojska 1 FU na odcinku od Mużakowa do Pieńska miały sforsować Nysę Łużycką i wedrzeć się na teren Saksonii w celu zniszczenia znajdujących się tam dywizji Grupy Armii (GA) „Środek” i dotarcia do Łaby w pasie od Torgau do Pirny na południe od Drezna. Dyrektywa nr 00211/op. nakazała wykonać to zadanie $34 \mathrm{KS}$ z $5 \mathrm{AGw}$. wspomaganym przez $4 \mathrm{KPanc}$. Gw., trzem lewoskrzydłowym dywizjom z 2 AWP i 1 KPanc. WP, 254 DS z 52 A wraz z 7 KZmech. Gw. oraz 1 KKGw. Kiedy poddamy analizie pełną treść dyrektywy nr 00211/op. dowódcy frontu o przejściu wojsk do ofensywy na wybranych odcinkach frontu, okazuje się, że zadanie dotarcia do Drezna nad Łabą otrzymał także dowódca 5 AGw., gen. Żadow. To zmienia postrzeganie całej operacji. Od ponad pół wieku w pracach poświęconych 2 AWP powiela się błędny pogląd, że wojsko Świerczewskiego i jednostki sowieckiej 52 A uratowały od klęski na Łużycach przybyłe na pomoc dywizje $5 \mathrm{AGw}$. i czołgi $4 \mathrm{KPanc}$. Gw., które w tym celu ściągano $\mathrm{z}$ północy. Tymczasem w myśl dyrektywy nr 00211/op. 5 AGw. i 4 KPanc. Gw. otrzymały zadanie sforsowania Nysy Łużyckiej pod Mużakowem i wyprowadzenia natarcia na osi Hoyerswerda-Schwepnitz-Drezno (pn.-zach. dzielnice).

27 Tony Le Lissier, Żukow na linii Odry. Rozstrzygajaca bitwa na przedpolach Berlina, tłum. Tomasz Szlagor (Wrocław: Wyd. Dolnośląskie, 2011), 125-127; Geoffrey Roberts, Generat Stalina. Życie Gieorgija Żukowa, tłum. Janusz Ochab (Kraków: Wyd. „Znak”, 2014), 260. 
Dyrektywa bardzo precyzyjnie określiła linię rozgraniczenia wojsk 5 AGw. i 4 KPanc. Gw. z 2 AWP i 1 KPanc. WP wzdłuż osi Weißwasser-Wittchenau-Kamenz. ${ }^{28} 5$ AGw. i 4 KPanc. Gw. otrzymały zadanie dojścia do Drezna niemalże ramię $\mathrm{w}$ ramię $\mathrm{z}$ piechotą i czołgami Wojska Polskiego. Niezrozumiała jest koncepcja Kaczmarka, który w skład „zgrupowania zabezpieczającego", które bezpodstawnie powołał do życia na kartach swoich publikacji, włączył tylko 2 AWP i 52 A. Widzimy, że zadanie dotarcia do Drezna otrzymała także 5 AGw. i 4 KPanc. Gw.

Jeśliby wziąć pod lupę dyrektywę nr 00211/op., to wynika z niej bardzo czytelnie, że 52 A miała nacierać na trzech rozbieżnych kierunkach. Niech czytelnik osądzi zresztą sam:

- 7 KZmech. Gw. i 254 DS wyprowadza natarcie na Drezno w kierunku zachodnim;

- 50 DS i 111 DS wyprowadzają natarcie na Reichenbach i Görlitz na południe;

- 31 DS, 214 DS i 373 DS odbijają Lauban (Lubań). ${ }^{29}$

Wbrew temu, co pisał Kaczmarek, nie znajdziemy w dyrektywie nr 00211/op. podstaw do twierdzenia, że 52 A miała nacierać na Drezno częścią swoich sił, a na pozostałych odcinkach przejść do twardej obrony. Cóż to miała być „twarda obrona”, skoro trzeba było wyprowadzić natarcie na Görlitz i Lubań? Jak na dziewięć dywizji strzeleckich (294 DS dotarła przed ofensywą z Wrocławia) natarcie na trzech rozbieżnych kierunkach było zadaniem wyjątkowo skomplikowanym i niemającym wiele wspólnego $\mathrm{z}$ „twardą obroną”. 52 A miała jednym korpusem strzeleckim wyprowadzić natarcie na południe w kierunku Lobau-Görlitz i związać odwody 4 APanc. i GA „Środek”. Prócz tego 52 A miała wesprzeć 7 KZmech. Gw. w natarciu na Drezno dwiema dywizjami (254 DS i 294 DS). ${ }^{30}$ Atakować mieli więc wszyscy. W dyrektywie nr 00211/op. znajduje się zdanie „na lewej flance

28 ЦАМО, f. 328: 5 гв. А (dalej: f. 328), op. 4852, d. 246, Журналы боевых действий 5 гв. A (dalej: Dziennik działań bojowych 5 AGw.) 1-30.04.1945 r., b.m., b.d., 21-22, dostęp październik 23, 2020, https://pamyat-naroda.ru/documents/view/?id=235982902\&backurl=q\%5C5\%20 \%D0\%B3\%D0\%B2.\%20\%D0\%90,\%20::use_main_string\%5Ctrue::group\%5Cjbd::types\%5Cjbd\&static_hash=6af24d65988c179c0ab39a6926db7c5av6. Zadanie dotarcia do Drezna przez 34 KS z 5 AGw. i 4 KPanc. Gw. było znane polskim badaczom nie później niż w 1965 r. i opisane jest w pkt. 3 wyciągu z dyrektywy nr 00211/op. w t. 3 zbioru dokumentów źródłowych.

29 ЦАМО, f. 408: 52 А (dalej: f. 408), op. 9991, d. 447, Журнал боевых действий 52А 1-30.04.1945 r. (Dziennik działań bojowych 52 A), b.m., b.d, 4-5, dostęp wrzesień 15, 2020, https://pamyat-naroda.ru/documents/view/?id=136690912\&backurl=q\%5C52\%20A::use_main_string\%5Ctrue::group\%5Cjbd::types\%5Cjbd::page\%5C4\&static_hash=fb52d3d5f62 feaa893b313084cdd140dv6.

30294 DS została włączona do zgrupowania bojowego, którego trzon stanowiły 7 KZmech. Gw. i 254 DS w trzecim dniu operacji łużyckiej i przerzucona transportem kołowym do Weißenbergu. 
przejść do twardej obrony", co peerelowscy badacze odnieśli do zadania pozostałych dywizji 52 A. Tymczasem wystarczyło tylko wczytać się w tekst i skonfrontować go z rozkazem dowódcy 52 A nr 007/op. z 12 kwietnia 1945 r., w którym ten ostatni nakazał dowódcy 111 DS w drugim dniu operacji zająć Görlitz. ${ }^{31}$ Wszelkie wątpliwości wyjaśnia komunikat (ros. краткая сбодка) szefa Wydziału Operacyjnego 52 A sporządzony kilka dni po zakończeniu wojny. Odnajdziemy tam streszczenie zadania $52 \mathrm{~A}$ w operacji łużyckiej, opis przebiegu walk, tabele strat własnych i przeciwnika, opis doświadczeń wyniesionych z pola walki. Autor dokumentu tak pisał o zadaniu 52 A w operacji łużyckiej: „Powaga postawionego zadania sprowadzała się do zajęcia części terytorium przeciwnika z miastami Bautzen i Görlitz, który charakteryzował się silnymi węzłami komunikacji kolejowej i drogowej. Z głównej przyczyny zaś w tym, że swoim natarciem wojska 52 Armii ubezpieczały lewe skrzydło frontu w operacji berlińskiej". ${ }^{32}$

Myślę, że to przekreśla spory o określenie zadań 2 AWP i 52 A w operacji łużyckiej. W dyrektywie nr 00211/op. nie było ani słowa o istnieniu "zgrupowania zabezpieczającego”, „zgrupowania wiążącego” i wzmacnianiu blokady Wrocławia. Jeśli dowódca 52 A otrzymał rozkaz wyprowadzenia natarcia w kierunku na Görlitz-Lubań, to równocześnie wziął na siebie obowiązek ubezpieczenia lewego skrzydła wojsk $1 \mathrm{FU}$ od południa. Jak równolegle miała to zadanie realizować 2 AWP? A przecież tak twierdził Kaczmarek i historycy peerelowscy. Nie można zatem zarzucać Świerczewskiemu „bezmyślnego parcia na Drezno”, gdyż to był priorytet 2 AWP i 1 KPanc. WP w operacji łużyckiej. Natarcie na Drezno było jedynym zadaniem polskiego zgrupowania bojowego, jakie marszałek Koniew powierzył w dyrektywie nr 00211/op. Świerczewskiemu i jego żołnierzom. O rzekomo ciążącym na nim obowiązku zabezpieczenia lewego skrzydła wojsk 1 FU nacierających na Drezno pisali i w dalszym ciągu piszą polscy autorzy. Tyle że wprowadzają swoich czytelników w błąd i nie mają ku temu podstaw. Dowódca 2 AWP otrzymał rozkaz wyprowadzenia natarcia przez Nysę Łużycką na Drezno trzema dywizjami piechoty i korpusem pancernym. ${ }^{33}$

\footnotetext{
31 ЦАМО, f. 408, op. 9991, d. 447, Dziennik działań bojowych 52 A, b.m., b.d., 5.

32 Ibid., Краткая сводка боевого опыта войск 52 А за апрель месяц 1945 г. (Komunikat o bojowych doświadczeniach 52 Armii za miesiąc kwiecień 1945 r.), b.m., 16 V 1945 r., 133, dostęp sierpień 3, 2020, https://pamyat-naroda.ru/documents/view/?id=111677995\&backurl= q\%5C4\%20\%D0\% BA\% D1\%82.

33 ЦАМО, f. 236, op. 2673, d. 2583, Dyrektywa dowódcy 1 FU marszałka Iwana Koniewa nr 00211/op. z 8 IV 1945 r. w Dziennik działań bojowych 1 FU w okresie 1-30.04.1945 r., 66, dostęp grudzień 15, 2020, https://pamyat-naroda.ru/documents/view/?id=10204228\&backurl= q\%5C1\%20\%D0\%A3\%D0\%BA\%D1\%80\%D0\%A4::use_main_string\%5Ctrue::group\%5Cjbd:: types\%5Cjbd::page\%5C7\&static_hash=b90b323e9322a0a9cd4825ce261029c5v6.
} 
Polscy badacze, którzy nie dotarli do rozkazów dowództwa 1 FU bądź zignorowali ten materiał źródłowy, nie wytłumaczyli czytelnikom swoich książek, jak też 2 AWP miała wyprowadzić natarcie na zachód, pokonując $90 \mathrm{~km}$ w trzy doby, a jednocześnie ubezpieczać przed kontratakiem z południa wojska 1 FU. Trzy lewoskrzydłowe polskie dywizje piechoty, tj. 5 DP, 8 DP, 9 DP, $z$ korpusem pancernym stanowily trzon zgrupowania uderzeniowego. Pozostałe dwie polskie dywizje piechoty, 7 DP i $10 \mathrm{DP}$, znajdowały się na prawym skrzydle ugrupowania bojowego 2 AWP. W takim razie zasadne jest pytanie: jak polskie dywizje miały osłonić zgrupowanie uderzeniowe $w$ natarciu na Drezno przed kontratakiem w bok $7 \mathrm{KZmech}$. Gw. i 254 DS, kiedy pas natarcia 2 AWP znajdował się na prawej flance 52 A i 7 KZmech. Gw.? Kto w końcu kogo miał tu osłaniać? Dlatego o walkach na Łużycach w Polsce Ludowej stworzono mnóstwo mitów, które były wynikiem karygodnego zaniechania lub celowego pominięcia niektórych źródeł. Konsekwencją błędów była seria pomyłek. Historycy wojskowości pół wieku temu wykreowali fikcyjny podział wojsk 1 FU na zgrupowania uderzeniowe, zabezpieczające i wiążące. Tymczasem dyrektywa nr 00211/op. określiła zadania bojowe dla 2 AWP i 52 A następująco: „52 Armia - opanować przedmieścia Drezna [...] w drugim i trzecim dniu natarcia zająć Lauban, Görlitz, Bautzen; 2 Armia - przerwać obronę przeciwnika trzema dywizjami na odcinku Rothenbug - OberFowerk i nacierać w ogólnym kierunku na NeuSärichen - Welka - Drezno [...] korpus pancerny trzeciego dnia osiągnąć rubież Lichtenberg - Radeberg" ${ }^{34}$

Radeberg znajdował się $5 \mathrm{~km}$ od wschodnich granic Drezna i był dla miasta tym, czym dla Warszawy był wtedy Wawer. Dziś mało się o tym mówi, ale Rosjanie pilnowali, aby oddziały lWP samodzielnie nie wyszły nad Łabę i nie nawiązywały kontaktu $\mathrm{z}$ armią amerykańską. Mam nieodparte wrażenie, że badacze $\mathrm{z}$ minionej epoki w swoich publikacjach bronili „jak lwy” honoru Stawki Naczelnego Dowództwa Armii Czerwonej, geniuszu Józefa Stalina i talentu Iwana Koniewa. Kiedy nie dopatrzyli się, kto miał osłaniać lewe skrzydło wojsk $1 \mathrm{FU}$ przed kontrnatarciem z południa, to wymyślili sobie, że ten ciężar musiała wziąć na siebie 2 AWP. Obwiniali później Świerczewskiego, że „uparcie” parł na Drezno, mając za plecami i na lewym skrzydle odwodowe dywizje GA „Środek”. Znali tylko wyciąg z dyrektywy nr 00211/op. i nie przyjmowali do wiadomości trudnej prawdy, że marsz. Iwan Koniew, numer drugi w hierarchii sław Armii Czerwonej, zlekceważył zagrożenie z rejonu Görlitz i nikomu nie powierzył osłony lewego skrzydła zgrupowania wojsk nacierających na Drezno.

\footnotetext{
34 Ibid., Pkt 5 i 6 dyrektywy dowódcy 1 FU nr 00211/op z 8.04.1945 r. Zob. też Stąpor, Organizacja i zadania, 3:203-204. We wcześniejszej publikacji Kaczmarek pisał, że dyrektywa nr 00211/op. nie nakazywała dowódcy 2 AWP zdobywania Drezna; zob. Kaczmarek, W bojach, 65.
} 
Tyle że marsz. Koniew był wybitnym dowódcą, przewidział zagrożenie z południa i ubezpieczył się przed kontrnatarciem z rejonu Görlitz. Przez długie lata nie znaliśmy pełnej treści dyrektywy nr 00211/op., a konkretnie jej punktu ósmego o zadaniu $1 \mathrm{KKGw}$. w operacji łużyckiej. ${ }^{35}$ Ale musiał ją znać Kaczmarek i badacze z Wojskowego Instytutu Historycznego. ${ }^{36}$

Rosjanie uważali, że w obliczu konieczności stoczenia bitwy o Berlin uporczywa obrona Łużyc nie ma większego sensu. W konsekwencji, pod Dreznem nie powinno być dużych sił niemieckich. W tym rozumowaniu było wiele racji, ale Rosjanie nie wiedzieli, że Adolf Hitler nie wierzył w ofensywę Armii Czerwonej na berlińskim kierunku operacyjnym. Sądził natomiast, że główne uderzenie Stawka wyprowadzi właśnie przez Saksonię. Tuż przed ofensywą zwiad lotniczy dostrzegł duży ruch na linii kolejowej z Görlitz przez Weißenberg do Cottbus. To były eszelony z czołgami 21 DPanc. i 10 DPanc. SS „Frundsberg”. Koniew oczekiwał ich pod Görlitz i na przedpolach Drezna, dlatego powierzył ubezpieczenie lewego skrzydła wojsk nacierających na Drezno $1 \mathrm{KKGw}$. gen. Wiktora Baranowa i 2 Armii Lotniczej. W pkt. 8 dyrektywy nr 00211/op. z 8 kwietnia 1945 r. czytamy, że $1 \mathrm{KKGw}$. miał przeprawić się przez Nysę Łużycką w drugim dniu operacji w ślad za $7 \mathrm{KZmech}$. Gw. pod Ullersdorfem i rozwinąć powodzenie w kierunku południowym, aby do 21 kwietnia 1945 r. sforsować Łabę pod Pirną na południe od Drezna, zająć Glashütte i skierować się na Diěčin. Korpus Baranowa miał przeprowadzić dywersję na tyłach wroga spełniając rolę strażnika zgrupowania wojsk $1 \mathrm{FU}$ nacierających na Drezno. Podobną rolę miał pełnić 7 KKGw. w szyku wojsk 1 FB Żukowa, który wypełniał lukę między 1 AWP a 47 A w pierścieniu okalającym Berlin. Fragment dyrektywy nr 00211/op. odnoszący się do zadań $1 \mathrm{KKGw}$. zacytuję ad litteram, gdyż w tym momencie są to słowa niezwykle ważne: „Zadaniem korpusu kawalerii jest wyjść na tyły görlicko-drezdeńskiej grupy przeciwnika, niszczyć jego tyły, sztaby, węzły łączności, podchodzące rezerwy i wycofujące się oddziały. Działać śmiało, zdecydowanie, nie oglądając się za siebie". ${ }^{37}$

Z kolei, następny punkt dyrektywy odnosił się do zadań bojowych 2 Armii Lotniczej: „Nie dopuścić do podejścia rezerw przeciwnika od strony Drezna”. ${ }^{38}$

\footnotetext{
35 Stąpor, Organizacja i działania, 3:203-204.

${ }_{36}$ W monografii 2 AWP z 1968 r. Kaczmarek przywołuje sowieckie źródła w postaci rozkazów dowódcy 1 FU i sowieckich związków operacyjnych do operacji berlińskiej przy pomocy prawidłowo określonych sygnatur, co świadczy o pełnej znajomości treści dyrektywy nr 00211/op, zob. Kaczmarek, Druga, passim.

37 Zob. ЦАMO, f. 236, op. 2673, d. 2583, Dziennik działań bojowych 1 FU, pkt 8 dyrektywy dowódcy 1 FU nr 00211/op z 8.04.1945 r., 67.

38 Ibid., pkt 9 dyrektywy, 68.
} 
Schemat 2.Zadania bojowe wojsk 1 FU na drezdeńskim kierunku operacyjnym wg dyrektywy 00211/op.

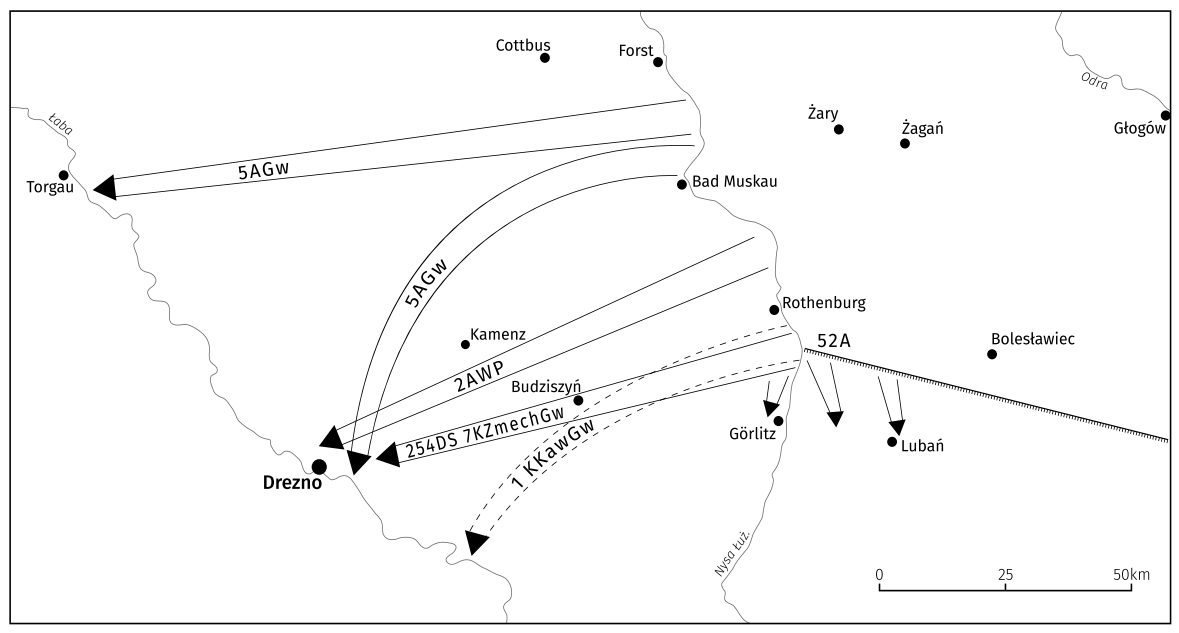

Źródło: oprac. własne autora

W świetle przytoczonych wyżej argumentów widzimy wyraźnie, dlaczego badacze peerelowscy, z Kaczmarkiem na czele, nie chcieli dysponować pełnym tekstem dyrektywy nr 00211/op. Operowanie wyciągiem było bowiem dogodne dla obrońców dobrego imienia marsz. Koniewa i gen. Pietrowa. Wyciąg z dyrektywy nr 00211/op. zawarty w trzecim tomie dokumentów źródłowych z 1965 r. nie objął pkt. 8, a właśnie tam opisano zadanie bojowe $1 \mathrm{KKGw}$. w operacji łużyckiej. Miał on osłonić lewe skrzydło wojsk $1 \mathrm{FU}$ nacierających na Drezno i absorbować odwody niemieckie, ale tego zadania nie wykonał. $\mathrm{Z}$ prostego zresztą powodu. Po pierwszym dniu ofensywy i raportach zwiadu w sztabie $1 \mathrm{FU}$ zlekceważono zgrupowanie Schörnera pod Görlitz i wysłano korpus kawalerii na północny-zachód od Drezna. Koniew po latach nie chciał o tym pamiętać. W obszernej autobiografii powołał się na tekst dyrektywy podpisanej przez Stalina 3 kwietnia 1945 r., która była podstawą opracowania dyrektywy nr 00211/op. Wedle jego wersji 2 AWP i część 52 A zabezpieczały zgrupowanie główne wojsk 1 FU w natarciu na Berlin, wykonując „pomocnicze uderzenie w ogólnym kierunku na Drezno". ${ }^{39}$ Ale to wymówka. Nikt nie chciał i nie śmiał tego kwestionować. Plan operacji berlińskiej nie nakładał na wojska 1 FU Koniewa zadania natarcia na Berlin. Założono to hipotetycznie $\mathrm{w}$ razie trudności wojsk $1 \mathrm{FB}$ z przełamaniem niemieckich pozycji obronnych na Odrze. Cenzor nie mógłby pozwolić w tych latach na jakąkolwiek krytykę poczynań

39 Iwan Koniew, Notatki dowódcy frontu 1943-1945, tłum. Piotr Marciniszyn i Czesław Waluk (Warszawa: Wyd. Ministerstwa Obrony Narodowej, 1986), 469-470. 
5.

к иоходу третьего дня операции - БАУЦАН, ЛОВАУ, ЛАУВАН.

7 ГВ МК ввести в прорев С рубева вөлевноћ дороги, что 6 ки. вап, р. НЕЯСЕ в нап-

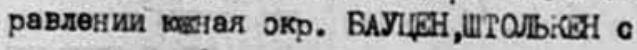
sадачей $\mathrm{K}$ иоходу второго дня операции овладеть районом ивнее и йо-восточнее БАУЦयु, на третия день операиии овладеть

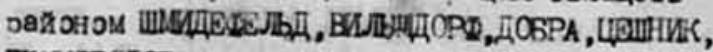
PQOKEREPCIOPE.

BOCBMOR: Комачдиру 1 ГB Кав.Корпуса, Корпуо ввести в прорнв на участке 52 A

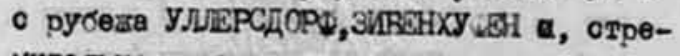
мительно раввивая наступление в обцем натравлениИ севернее ЛОБАУ, ОМПLХ, ЗЕВИИГЦ, ГЛАСХГТЕ, охода форбировать на четвертый день операция р. 2ЈЉБА на участке шГАТВЕЛळ, ДЗЧин и овладеть главнеми оилами корпуса рая̆ оном ГЛАССХTTЕ. Задача кав.корпуса выһти на тыле ГерлицДРЕЗДВНСКСО трупть противника, громить тыль, штаби, уяль связи, подходяцие резерви и отходящие части противника. Корпусі, действовать смедо и рөшительно, не огляцнваться наэад, узлы оэпротивления противника, особөнно в крупных населенных пунктах, обходить.

деватОв: Командариу 2 Воядушноћ.

a/ Прикрнгь с воэлуха сосредотхение и действия воиок гұавнои $r$ гупировки, особеніи танковых ариish.

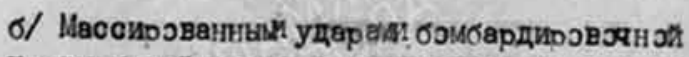
и штурмово авиация содействовать воћскам

Źródło: ЦАMO, f. 236, op. 2673,

d. 2583, Zadanie 1 KKGw. w dyrektywie 00211/op. z 8 IV 1945 r., 67 
dowództwa 1 FU w operacji berlińskiej. Pamiętajmy, że w połowie lat sześćdziesiątych autorytet Koniewa był w Polsce Ludowej niepodważalny. Marszałek był popularny, gdyż był dowódcą Armii Czerwonej, który ocalił Kraków od zniszczeń. Na przełomie lat pięćdziesiątych i sześćdziesiątych XX w. pełnił m.in. funkcje wiceministra obrony ZSRS, pierwszego dowódcy wojsk Układu Warszawskiego i cieszył się zaufaniem Nikity Chruszczowa. Tymczasem Świerczewski nie żył od kilkunastu lat i choćby z tego powodu mógł zostać kozłem ofiarnym zaciętych walk na Łużycach. W świetle tego, co zdarzyło się na froncie pod Dreznem w drugiej dekadzie kwietnia 1945 r., należało takiego „kozła ofiarnego” znaleźć.

Koniew spodziewał się odwodów Schörnera na przedpolu Drezna i nie miał pojęcia o silnych odwodach niemieckiej 4 APanc. w rejonie Görlitz i Lubania. Zawiódł wywiad Armii Czerwonej i organy rozpoznania frontu. Przyznał to przed laty nawet Kazimierz Kaczmarek. ${ }^{40}$ Kiedy pierwszego dnia ofensywy zlokalizowano 21 DPanc. i 10 DPanc. SS „Frundsberg” pod Cottbus, widmo zagrożenia kontrnatarciem z rejonu Görlitz ustało. Dlatego w nocy z 16 na 17 kwietnia 1945 r., tj. drugiego dnia ofensywy, szef sztabu $1 \mathrm{FU}$, gen. Pietrow, zmienił zadanie bojowe $1 \mathrm{KKGw}$. Wedle pkt. 8 dyrektywy nr 00211/op. korpus Baranowa miał wyjść na zaplecze niemieckiej 4 APanc. w rejonie Görlitz. Po pierwszym dniu ofensywy gen. Pietrow skierował $1 \mathrm{KKGw}$. na tyły znacznie groźniejszego w tym momencie cottbuskiego zgrupowania wojsk niemieckich, które zlokalizowano na północny zachód od Drezna. ${ }^{41}$ Szef sztabu 1 FU zachował się jak pokerzysta i pozostawił swemu losowi lewe skrzydło wojsk nacierających na Drezno - wszak lotnictwo $1 \mathrm{FU}$ zajęte nad Berlinem zostawiło niebo nad Łużycami samolotom Luftwaffe. Oficerowie $1 \mathrm{FU}$ z doświadczonym szefem sztabu zwrócili oczy na Cottbus i tam spodziewali się przeciwnika. Inna sprawa, że na drezdeńskim kierunku operacyjnym w razie kłopotów można było liczyć na ok. 550 czołgów i dział pancernych, nie mniej niż 2,1 tys. dział i moździerzy i 160-170 tys. żołnierzy polskich i sowieckich. To była siła, która mogła przeciwstawić się każdemu przeciwnikowi. Poza tym, w drodze z Prus Wschodnich była $31 \mathrm{~A}$, zaś w razie potrzeby można było rzucić na wroga 2 Armię Lotniczą. Sztab 1 FU drugiego dnia operacji zaczepnej nie martwił się o kierunek drezdeński. Dla losów wojny kierunek ten miał zresztą drugorzędny charakter.

\footnotetext{
40 Kaczmarek, $W$ bojach, 54.

${ }_{41}$ Zob. ЦАМО, f. 236, op. 2673, d. 2736, Rozkaz szefa sztabu 1 FU nr 00127/op. z 17 IV 1945 r. w Журнал боевых действий 1 KK Gw. 1-30.04.1945 r., b.m., 14-15, dostęp wrzesień 12, 2020, https://pamyatnaroda.ru/documents/view/?id=114814088\&backurl $=\mathrm{q} \% 5 \mathrm{C} 1 \% 20$ \%D0\%B3\%D0\%B2.\%20\%D0\%BA\%D0\%BA,\%20::use_main_string\%5Ctrue::group\%5Cjbd::t ypes\%5Cjbd::page\%5C5\&static_hash=6af24d65988c179c0ab39a6926db7c5av6.
} 
Schemat 3. Zadania bojowe wojsk 1 FU na drezdeńskim kierunku operacyjnym wg szefa sztabu $1 \mathrm{FU}$ nr 00127/op. z 17 kwietnia 1945 r.

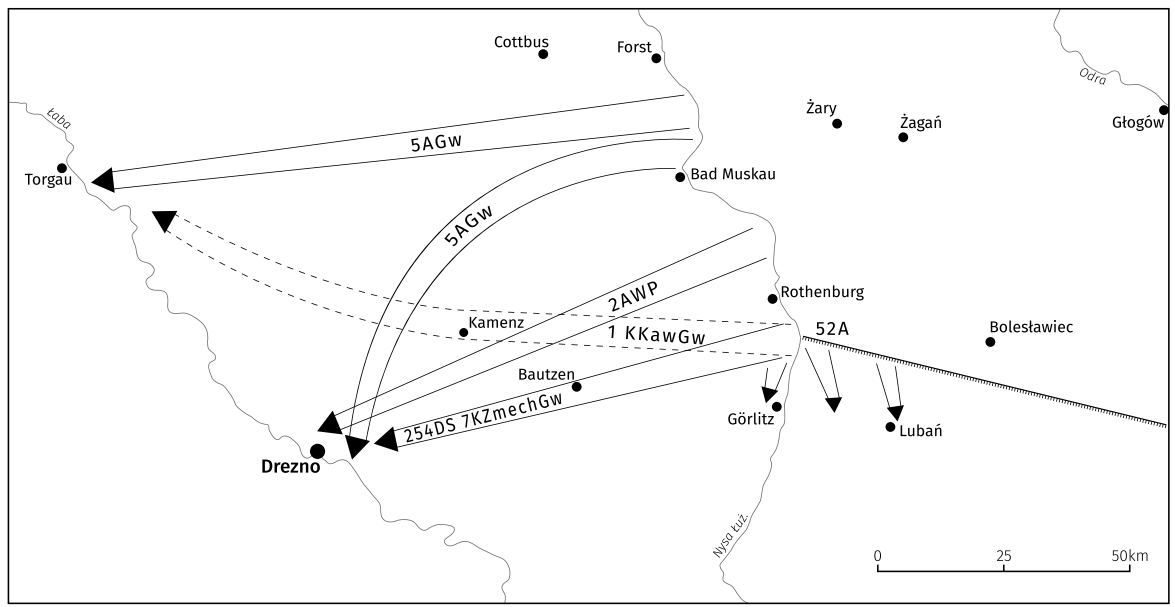

Źródło: oprac. własne autora

\section{Pod pręgierzem historii czy historyków?}

Karol Świerczewski był renegatem, czekistą i do szpiku człowiekiem sowieckim. W czasie wojny 1920 r. miał szansę stanąć po właściwej stronie, ale opowiedział się przeciw sprawie naszej niepodległości. Walczył z oddziałami Wojska Polskiego pod Warszawą, został nawet ranny, zaś w latach trzydziestych XX w. szkolił dywersantów, których przerzucano na teren Polski. Jako zwierzchnik sądowy hurtem zatwierdzał wyroki śmierci wydane na żołnierzy Armii Krajowej, czego nie robił np. gen. Stanisław Popławski i niektórzy pozostali sowieccy dowódcy w polskich mundurach. Śmierć $\mathrm{z}$ ręki banderowców tych ponurych faktów nie usunie z jego biogramu. Celem tegoż artykułu nie jest poprawianie Świerczewskiemu noty w historii. Tu chodzi o coś więcej. Peerelowscy badacze, a w ślad za nimi zagraniczni autorzy, pisząc o walkach pod Dreznem rzucili cień nie tylko na sylwetkę Świerczewskiego, ale na ludowe Wojsko Polskie. Utrwalony od lat przekaz jest nadal ten sam: dowódca 2 AWP doprowadził błędami w dowodzeniu do kryzysu na Łużycach, ponieważ chciał zdobyć „coś dużego” i „nierozumnie parł na Drezno”. Miał pilnować lewego skrzydła zgrupowania bojowego 1 FU przed kontrnatarciem z południa, a pchał się na zachód. Na to dodatkowo nakładają się dość rozpowszechnione plotki o pijaństwie Świerczewskiego i jego ignorancji w sprawach operacyjnych. Chętnie przywoływany jest też zarzut klęski jego dywizji pod Wiaźmą i brak sukcesów w hiszpańskiej wojnie domowej. Spójrzmy na niektóre tylko przykłady. 
Popularny w strefie rosyjskojęzycznej i beztroski w poglądach Aleksiej Isajew stwierdził bez ogródek, że: „Nawet skuteczny kontratak w lewe skrzydło 1 Frontu Ukraińskiego nie zmusił generała Świerczewskiego do porzucenia natarcia na Drezno". 42

Poważany i chętnie czytany w Polsce Władimir Bieszanow pisał o Świerczewskim w szczytowym momencie sukcesów kontrofensywy Schörnera w następujący sposób: „W sztabie generała Karola Świerczewskiego, mizernie orientującego się w sytuacji, wciąż kreślono plany natarcia na Drezno [...] Oj! Jak bardzo chciał Świerczewski zdobyć coś naprawdę dużego". ${ }^{43}$

Z kolei Jacek Domański tak pisze o zachowaniu Świerczewskiego na Łużycach: „Generał Świerczewski wydając rozkazy nie znał często położenia własnych jednostek oraz oddziałów przeciwnika. Obraz sytuacji operacyjnej i taktycznej na froncie przesłaniał generałowi uporczywy zamiar zdobycia Drezna, który doprowadził do tragedii, jaka rozegrała się w okolicach Budziszyna".44

Rosyjskim badaczom trzeba przypomnieć, że w krytycznych dniach 21-22 kwietnia 1945 r. mizernie orientował się w sytuacji na Łużycach przede wszystkim gen. Pietrow, szef sztabu 1 FU. Świerczewski, prowadząc natarcie na Drezno, już w drugim dniu ofensywy zorientował się w rysującym się zagrożeniu z południa. W nocy z 17/18 kwietnia $1945 \mathrm{r}$. Świerczewski wysłał do sztabu $1 \mathrm{FU}$ pierwsze raporty mówiące, że na lewym skrzydle zgrupowania uderzeniowego 2 AWP doszło do niebezpiecznego włamania. Od razu zawrócił z natarcia na Drezno dwie brygady pancerne (2 BPanc. i 4 BPanc. z 1 KPanc.), 8 DP i osłonił się 1 Brygadą Zmotoryzowaną i jednostkami artylerii. ${ }^{45}$ Reakcja dowódcy 2 AWP na zagrożenie z południa była prawidłowa, ale gen. Pietrow to zignorował. W obliczu rozwijającego się kontrnatarcia 20 DPanc. i 1 Dywizji Panc.-Spad. „Hermann Göring” z rejonu Görlitz na północ ze sztabu 1 FU nad ranem 21 kwietnia nadszedł rozkaz nr 00215/op., który obligował Świerczewskiego do kontynuowania natarcia na Drezno: „Armia ma kontynuować natarcie w ogólnym kierunku na Elstra - Drezno. Zgrupowanie uderzeniowe w składzie trzech dywizji znajdzie się w centrum tego ugrupowania w kierunku na Elstra. Do końca 21 kwietnia armia ma dojść do rubieży Kamenz - Elstra [...] W dalszym ciągu nacierać na Drezno. 1 KPanc do końca 21 kwietnia zająć rubież Pulsnitz - Ottendorf - Radeberg". ${ }^{46}$

\footnotetext{
42 Алексей Исаев, Берлин 45-го. Сражение в логове зверя (Москва: Эксмо, 2007), 566 i n.

43 Wladimir Bieszanow, 1945 - rok zwycięstwa tłum. Galina Palacz i Andrzej Palacz (Warszawa: Inicjał Andrzej Palacz, 2013), 370.

44 Domański, Budziszyn 1945, 80.

45 Zob. rozkazy szefa sztabu 2 AWP do dowództw 8 DP i 1 KPanc. z 18-19 IV 1945 r. nakazujące wykonanie przeciwuderzenia w kierunku Ullersdorf w celu zniszczenia wojsk nieprzyjaciela kontratakującego pod Niesky; zob. Stąpor, Organizacja i działania, 3:446 i n.

46 ЦАМO, f. 236, op. 2673, d. 2583, Dziennik działań bojowych 1 FU, 154-155.
} 
Widzimy wyraźnie, że marsz. Koniew oceniał sytuację na lewym skrzydle frontu inaczej. Był zajęty zdobywaniem Berlina. Wszak priorytetami Stalina był Berlin i dotarcie przed Amerykanami do Łaby. Podpułkownik Michał Kaseja, pomocnik szefa Wydziału Operacyjnego 2 AWP, był świadkiem rozmowy Pietrowa ze Świerczewskim. Szef sztabu 1 FU zakończył ją rozkazem: „Świerczewski, masz się osłonić jedną dywizją piechoty przed Schörnerem, a prawym goń na Drezno". ${ }^{47}$

Kaseja był zaskoczony, że szef sztabu $1 \mathrm{FU}$ ignoruje niebezpieczeństwo z południa. Wszak Świerczewski alarmował Pietrowa o niemieckich dywizjach pancernych, które coraz mocniej napierały z rejonu Görlitz już trzeci dzień. W monografiach jednostek należących do 2 AWP i 1 KPanc. znajdziemy opisy zażartych walk, które 1 Brygada Zmotoryzowana, 2 BPanc. i 4 BPanc. z 1 KPanc. WP, 8 DP, 9 Brygada Artylerii Przeciwpancernej i 2 Dywizja Artylerii stoczyły na południe od Niesky w dniach 18-20 kwietnia. Tymczasem w szczytowym momencie walk szef sztabu 1 FU lekką ręką zdemontował obronę postawioną skutecznie na lewym skrzydle ugrupowania bojowego na odcinku Dhiesa-Ödernit-Niesky, po czym nakazał Świerczewskiemu kontynuować natarcie na Drezno. Roman Zabilski, oficer bez stopnia i tłumacz $\mathrm{w}$ sztabie 2 AWP, tak zachował w swojej pamięci te krytyczne chwile: „Wszyscy byli zdenerwowani, a Świerczewski najbardziej. Klął jak szewc i nie mógł dodzwonić się do Koniewa. Wiedzieliśmy, że robi się coś niedobrego od strony Czechosłowacji, dlatego generał na wszelki wypadek trzymał ciężkie czołgi pod ręką. ${ }^{48}$

Krytyczne opinie wysuwane pod adresem Świerczewskiego i sztabu 2 AWP są chętnie przytaczane przez zagranicznych badaczy. Rosjanie zwykle akcentują "polskie” błędy, co jest oczywistym fałszowaniem historii. Wszak prócz płk. Mikołaja Prus-Więckowskiego wszyscy dowódcy związków taktycznych i oficerowie sztabu 2 AWP mieli identyczny rodowód co Iwan Koniew lub Iwan Pietrow. Rzecz jednak w tym, że po latach za ciężkie straty pod Dreznem obwinia się IWP. Błędy popełnione w dowodzeniu przez dowództwo 1 FU w operacji łużyckiej były usilnie bronione przez historyków w latach Polski Ludowej i dziś zbieramy tego owoce. Na potrzeby kłamliwej polityki historycznej wykreowano sylwetkę Świerczewskiego jako pijaka i ignoranta. Czy to jednak prawdziwy obraz?

\footnotetext{
47 Podpułkownik Michał Kaseja o walkach 2 AWP pod Budziszynem, zob. Narodowe Archiwum Cyfrowe, 2 Armia ludowego Wojska Polskiego, 33-T-2180, nagranie dźwiękowe z rozmowy Jerzego Łyżwy-Łyżwańskiego, Michała Kasei i Janusza Bobkowskiego, Budziszyn, 30 IV $1968 \mathrm{r}$.

48 Zbiory Ryszarda Popiela w Różankach, Relacja oficera bez stopnia Romana Zabilskiego, tłumacza języka polskiego w sztabie 2 AWP, złożona 23 VII 1980 r. w Gorzowie Wielkopolskim, 8 .
} 


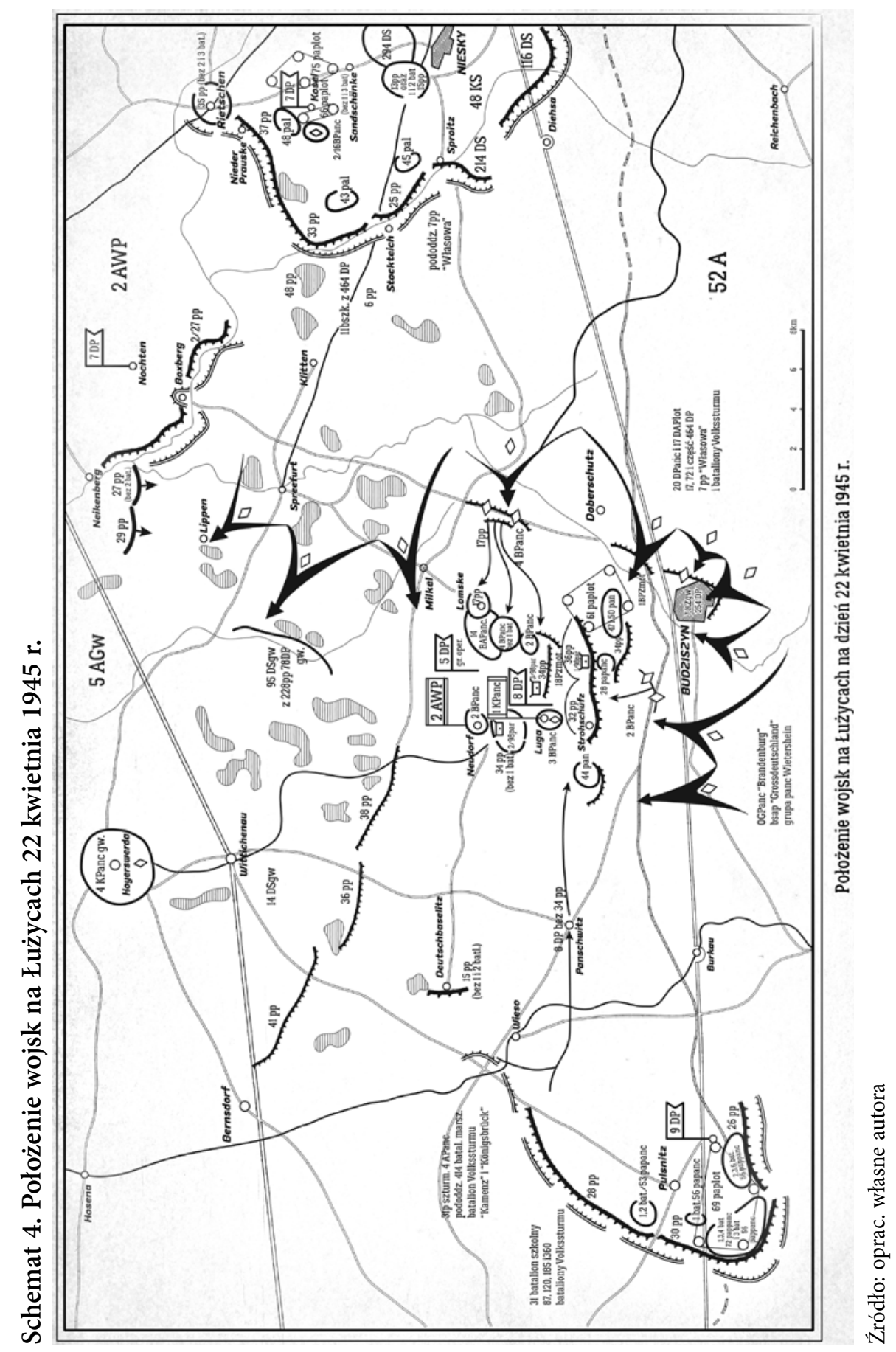


Świerczewski w istocie jest postacią ponurą i ciąży na nim mnóstwo zbrodni. Nie był jednak ignorantem, jak chcieliby to widzieć niektórzy badacze. W rzeczywistości był jednym z lepiej wykształconych oficerów Armii Czerwonej, którzy zostali delegowani do IWP. Miał też praktykę w dowodzeniu wojskami na szczeblu związku taktycznego. W tym przypadku ma rację Kusiak, który podkreślił jego zasługi oddane komunistom hiszpańskim w czasie wojny. Z początkiem lata 1937 r. wyznaczono go dowódcą 35 Dywizji Proletariackiej w V Korpusie Armii Ludowej. Dowodził nią już do końca swojego pobytu w Hiszpanii. Wyróżnił się jako dowódca tej dywizji w operacjach zaczepnych prowadzonych w okolicach Segovii (maj-czerwiec 1937 r.) i operacji bruneckiej na froncie madryckim. Wielkie sukcesy odniósł w sierpniu 1937 r. w operacji saragoskiej. W 1938 r. doceniono jego umiejętności taktyczne podczas walk odwrotowych na froncie aragońskim i katalońskim. ${ }^{49}$ Po powrocie do ZSRS obronił pracę doktorską w Akademii im. Michaiła Frunzego, gdzie przez dwa lata wykładał sztukę wojenną. Przypisywano Świerczewskiemu wytracenie w 1941 r. swojej dywizji rezerwowej pod Wiaźmą. W rzeczywistości, z kotła pod Wiaźmą wyprowadził kilkuset ludzi, w tym batalion medyczny, zaś Armia Czerwona straciła tam 4 armie ogólnowojskowe, 9 brygad pancernych, 31 pułków artylerii (ok. 400 tys. oficerów i żołnierzy). Rezerwowa 248 DS broniła odcinka frontu, na który nacierały dwie niemieckie dywizje, $\mathrm{w}$ tym jedna pancerna (6 DPanc.). ${ }^{50} \mathrm{Na}$ Łużycach Świerczewski prawidłowo zareagował na pogorszenie sytuacji na lewym skrzydle. Zatrzymał na trzy dni kontrofensywę feldmarszałka Schörnera z południa, po czym nakazano mu kontynuować natarcie na zachód. Wówczas to polskie zgrupowanie otrzymało uderzenie w swój odsłonięty lewy bok ze strony silnych odwodów GA „Środek". W wyniku zlekceważenia ostrzeżeń przez dowództwo 1 FU niemiecki kontratak wyprowadzony z południa przez dywizje 4 APanc. wyrządził olbrzymie szkody. Ręczne sterowanie polskimi jednostkami przez gen. Pietrowa doprowadziło do zniszczenia 7 KZmech. Gw., 254 DS w Budziszynie i 294 DS w Weißenbergu. ${ }^{11}$ Skutkiem błędnej decyzji dowództwa 1 FU było

\footnotetext{
49 Kusiak, Generat, 19.

50 Лев Лопуховский, Вяземская катастрофа 1941. Страшнейшая трагедия войнь (Москва: Яуза-Каталог, 2019), 484 i n.
}

51 Tylko te trzy wielkie jednostki sowieckie straciły łącznie około 6 tys. zabitych i kilka tysięcy rannych. Poległ dowódca 254 DS gen. Michaił Putiejko, jego zastępca ds. politycznych płk Siergiej Didkowskij, wszyscy dowódcy pułków i większość oficerów. W Budziszynie i Weißenbergu 7 KZmech. Gw. stracił 87\% czołgów i 77\% dział pancernych. Poległ również zastępca dowódcy 7 KZmech. Gw. gen. Władimir Maksimow, dowódca 25 BZmech. Gw. płk Łuka Dudka, wielu dowódców pułków, oficerów i ok. 3,5 tys. żołnierzy. Zob. Владимир Андрианов, 254 Черкасская стрелковая дивизия (Чебоксары: Чувашия, 2006), 106 і п.; Давид М. Баринов, Василий М. Бобров і Борис А. Денискин, Гвардейский Нежинский Кузбасский: О боевом пути 
wysunięcie na zachód osamotnionej 9 DP, która została okrążona i poniosła ciężkie straty. ${ }^{52}$

Pierwszym, który obciążył Świerczewskiego za klęskę oddziałów Armii Czerwonej, był gen. Iwan Korczagin. Uczynił to kilka dni po zakończeniu wojny. W raporcie z przebiegu walk $7 \mathrm{KZmech}$. Gw. utyskiwał na brak pomocy ze strony 2 AWP pod Budziszynem, która rzekomo wpadła w panikę bez większego nacisku ze strony wroga. To miało zdjąć z niego odium za klęskę, a przecież sprawcy kryzysu należało szukać wyżej. ${ }^{53}$ Korczagin obciążył Świerczewskiego, mimo że ten wykonał rozkaz gen. Pietrowa i zorganizował odsiecz dla otoczonej w Budziszynie 254 DS i 7 KZmech. Gw. Niestety, Korczagin nie wytrzymał nacisku wojsk niemieckich i nie czekając na polską odsiecz, wycofał się z miasta. Tylko w pierwszym dniu zaciekłych walk pod Budziszynem zawrócony z marszu na Drezno 1 KPanc. WP stracił około 60 czołgów i dział pancernych, a Świerczewski z oficerami sztabu walczył na pierwszej linii pod Kleinwelka. ${ }^{54} \mathrm{O}$ sprawnym zawróceniu $1 \mathrm{KPanc}$. WP spod Drezna i zorganizowaniu pomocy dla okrążonych Rosjan pisali nie tylko historycy. Z tego okresu walk mamy wiele relacji weteranów 2 AWP i 1 KPanc. WP. Przykładowo, Ludwik Pajdosz, zwiadowca 3 BPanc., wspominał po latach, że po niespodziewanym zawróceniu jego brygady spod Drezna oddział wydzielony składający się z 12 czołgów i dział pancernych wyprowadził z marszu natarcie na Budziszyn: „Otrzymaliśmy zadanie przeprowadzenia natarcia w celu rozbicia okrążenia i połączenia z 7 korpusem pancernym Armii Radzieckiej. $\mathrm{Z}$ tego natarcia wyszło cało tylko 2 czołgi i 2 działa pancerne. W tym boju został rozbity mój motocykl i ja sam ledwie wyniosłem głowę". ${ }^{55}$

Zgodnie z otrzymanym od szefa sztabu $1 \mathrm{FU}$ rozkazem Świerczewski 24 kwietnia 1945 r. zorganizował kontratak, w którym miał wziąć udział

Неж.-Кузбас. механизир. соединения в Великой Отеч. войне (Кемерово: Кн. Изд., 1985), 241-248.

52 Zob. „Rozkaz szefa sztabu 1 FU do dowódcy 2 AWP z 23 IV 1945” w Stąpor, Organizacja i działania, 3:584-585.

53 ЦАМО, f. 408, op. 9991, d. 412, Raport z przebiegu działań bojowych 7 Gwardyjskiego Zmechanizowanego Nieżyńsko-Kusbaskiego Korpusu za okres 1.04.-10.05.1945 r., b.m., 45, dostęp lipiec 25, 2020, https://pamyat-naroda.ru/documents/view/?id=450016474\&backurl =q\%5C7\%20\%D0\%B3\%D0\%B2.\%20\%D0\%BC\%D0\%BA\%20::use_main_string\%5Ctrue::group \%5Crep::types\%5Cdokladi:raporti:doneseniya:svedeniya::page\%5C2\&static_hash=2896e3d5a 3941fc37538579bf059abe4v3.

54 Roman Zabilski wspomina, że w krytycznym momencie walk pod Budziszynem otrzymał kanister z benzyną i granat, żeby zniszczyć akta sztabu 2 AWP. W tym czasie dowódca armii i wszyscy oficerowie sztabowi z pistoletami w dłoniach ruszyli tyralierą w stronę wroga, żeby zawrócić piechotę i odtworzyć linię bojową, zob. Zbiory Ryszarda Popiela w Różankach, Relacja oficera bez stopnia Romana Zabilskiego, tłumacza języka polskiego w sztabie 2 AWP, złożona 23 VII 1980 r. w Gorzowie Wielkopolskim, 11.

55 Archiwum Państwowe w Zielonej Górze, Komisja Historyczna ZBOWiD w Zielonej Górze, 89/554/0/71.12/809, Relacja Ludwika Pajdosza z 10.05.1974 r., b.m., 3. 
$7 \mathrm{KZmech}$. Gw. Ale jak delikatnie ujął to Zdzisław Stąpor, "natarcie $7 \mathrm{KZmechGw} \mathrm{i} 254$ DS prawie nie ruszyło z miejsca". ${ }^{56}$ Korczagin nie wytrzymał w Budziszynie nacisku porównywalnych liczebnie wojsk niemieckich i wycofał się na tyły 2 AWP. Nie docenił pomocy udzielonej przez wojsko Świerczewskiego. Dopiero 25 kwietnia 1945 r. gen. Pietrow w obliczu załamania się lewego skrzydła wojsk $1 \mathrm{FU}$ zgodził się na przerwanie natarcia na Drezno i z tygodniowym opóźnieniem nakazał Świerczewskiemu postawić pod Budziszynem zaporę przed dywizjami GA „Środek”. A można było ten plan wdrożyć w życie już 18 kwietnia i zostawić zdobycie Drezna 5 AGw. i 4 KPanc. Gw. Po latach całkowitą winą za chaos pod Budziszynem i sukcesy kontrofensywy Grupy Armii „Środek” obciążono dowódcę 2 AWP, co chętnie podjęli zagraniczni autorzy.

\section{Podsumowanie}

Od momentu zakończenia wojny w literaturze historycznej przedstawiany jest $\mathrm{z}$ gruntu fałszywy obraz przebiegu operacji łużyckiej. Wysiłek wojenny żołnierzy ludowego Wojska Polskiego w tej operacji postrzega się głównie przez pryzmat domniemanych błędów popełnionych przez dowódcę 2 AWP, gen. Karola Świerczewskiego. Jakiekolwiek te błędy były, czego nie można kwestionować, 2 AWP nie otrzymała zadania zabezpieczenia lewego skrzydła wojsk $1 \mathrm{FU}$, ale miała nacierać na Drezno. To stawia w nowym świetle ocenę dowodzenia polskim zgrupowaniem bojowym przez Świerczewskiego. Przez lata zarzucano mu bowiem wywołanie chaosu w zgrupowaniu wojsk nacierających na Drezno i brak dbałości o lewe skrzydło wojsk 1 FU. Tymczasem przyczyn chaosu na Łużycach trzeba szukać na szczeblu dowództwa frontu. Popełniono tam poważne błędy w ocenie potencjału odwodowych oddziałów GA "Środek” znajdujących się w rejonie Görlitz. Marszałek Koniew odstąpił od wprowadzenia zgodnie z pierwotnym planem operacji łużyckiej $1 \mathrm{KKGw}$. na południe od Budziszyna. Klęska na ulicach Lubania zimą 1945 r. niczego go nie nauczyła. Nie wiemy, czym ten manewr mógł się ostatecznie skończyć, lecz anulowano zadanie 1 KKGw., który liczył 18,4 tys. ludzi, stanowił równowartość trzech dywizji strzeleckich, miał w swoim składzie pułk czołgów i pułk wyrzutni rakietowych BM-13. Po pierwszym dniu ofensywy i informacjach organów rozpoznania groźniej przedstawiało się zgrupowanie niemieckiej 4 APanc. w rejonie Cottbus. Nikt w sztabach 1 FU, 2 AWP i 52 A po pierwszym dniu ofensywy nie miał wiedzy o podchodzących z południa niemieckich 20 DPanc., 1 Dywizji Panc.-Spad. „Hermann Görnig”, 17 DAPlot, 17 DP, 72 DP, 269 DP, Kampfgruppe Moser, kilku brygadach artylerii pancernej i kilku 
mniejszych grupach bojowych, które czekały na sowiecką ofensywę na północ od Lubania i Görlitz.

W trzecim dniu operacji berlińskiej, w toku walk na drezdeńskim kierunku operacyjnym, w sztabie 2 AWP prawidłowo rozpoznano rosnące zagrożenie z południa. Świerczewski zażegnał je w dniach 18-19 kwietnia 1945 r. własnymi siłami, ale nakazano mu kontynuować natarcie na Drezno. Musiał rzucić na powrót 1 KPanc. WP na zachód i odsłonić lewy bok swego zgrupowania bojowego na kontratak z południa. Obronę lewego skrzydła 2 AWP miały przejąć dywizje $52 \mathrm{~A}$, ale tego zadania nie wykonały. W konsekwencji, w dniach 23-27 kwietnia doszło do krytycznej sytuacji w rejonie Budziszyn-Weißenberg. Oddziały polskie i sowieckie poniosły tam poważne straty w ludziach i sprzęcie. Przeciwnik został jednak zatrzymany kilka kilometrów na północ od Budziszyna przez oddziały 2 AWP, 1 KPanc., $34 \mathrm{KS} \mathrm{z} 5$ A Gw. i 214 DS z 52 A. Po latach usłużni polscy badacze zdjęli z marszałka Koniewa i oficerów sztabu 1 FU odpowiedzialność za wywołanie chaosu pod Dreznem i przypisali wyłączną winę za błędy dowódcy 2 AWP. Zachowane dokumenty źródłowe tej wersji wydarzeń na Łużycach stanowczo przeczą, niestety w tym kierunku podąża od kilkudziesięciu lat narracja historyczna i trudno ją będzie naprowadzić na właściwe tory.

\section{Bibliografia}

\section{Archiwalia}

Archiwum Akt Nowych

Zbiór akt osobowych działaczy ruchu robotniczego - akta Karola Świerczewskiego Archiwum Państwowe w Zielonej Górze

Komisja Historyczna ZBOWiD w Zielonej Górze

Centralne Archiwum Ministerstwa Obrony Federacji Rosyjskiej

Fond 236: 1 Front Ukraiński

Fond 328: 5 Armia Gwardii

Fond 408: 52 Armia

Fond 3437: 7 Nieżyńsko-Kusbaski Korpus Zmechanizowany Gwardii

Fond 3465: 1 Żytomierski Korpus Kawalerii Gwardii

Centralne Archiwum Wojskowe Wojskowego Biura Historycznego

Dowództwo 2 Armii Wojska Polskiego

Narodowe Archiwum Cyfrowe

2 Armia ludowego Wojska Polskiego

Archiwa prywatne

Zbiory rodzinne Ryszarda Popiela

\section{Źródła drukowane}

Stąpor, Stanisław, red. Organizacja i działania bojowe ludowego Wojska Polskiego w latach 1943-1945. T. 3. Warszawa: Wyd. Ministerstwa Obrony Narodowej, 1965. 


\section{Literatura}

Андрианов, Владимир. 254 Черкасская стрелковая дивизия. Чебоксары: Чувашия, 2006.

Баринов, Давид М., Василий М. Бобров і Борис А. Денискин, Гвардейский Нежинский Кузбасский: О боевом пути Неж.-Кузбас. механизир. соединения в Великой Отеч. Войне. Кемерово: Кн. Изд., 1985.

Bahm, Karl. Berlin 1945. Tłum. Michał Kompanowski. Warszawa: Bellona, 2015.

Bieszanow, Władimir. 1945 - rok zwycięstwa. Tłum. Galina Palacz i Andrzej Palacz, Warszawa: Inicjał Andrzej Palacz, 2013.

Blum, Ignacy. „Sprawa 31 pułku piechoty. Tło, przebieg i charakter masowej dezercji żołnierzy 31 pp w 1944 roku." Wojskowy Przeglad Historyczny 10, nr 3 (1965): 39-63.

Bobkowski, Janusz. Kierunek Budziszyn. Warszawa: Wyd. Ministerstwa Obrony Narodowej, 1965.

Bobkowski, Janusz. W walce z czołgami. Z dziejów 9 i 14 brygady artylerii przeciwpancernej 2 armii WP. Warszawa: Wojskowy Instytut Wydawniczy, 1961.

Bobkowski, Janusz i Czesław Mirowski. Dziewiąta przeciwpancerna. $Z$ dziejów 9 Drezdeńskiej Samodzielnej Brygady Artylerii Przeciwpancernej. Warszawa: Wyd. Ministerstwa Obrony Narodowej, 1972.

Bodenmüller, Eduard. Con i Panther della Brandenburg. Febbraio-Maggio 1945. Genova: Soldiershop Publishing, 2015.

Domański, Jacek. Budziszyn 1945. Warszawa: Wyd. „Militaria”, 2009.

Gać, Stanisław. 7 Dywizja Piechoty: historia 7 Łużyckiej Dywizji Piechoty. Warszawa: Wyd. Ministerstwa Obrony Narodowej, 1970.

Garbowski, Henryk. W zaułkach frontu pod Budziszynem. Pruszków: Ofic. Wyd. „Ajaks”, 2003.

Ginalski, Edmund. 22 Pułk Artylerii Lekkiej. Zarys dziejów 1944-1947. Warszawa: Wyd. Ministerstwa Obrony Narodowej, 1974.

Ginalski, Edmund. 40 pułk artylerii lekkiej. Zarys dziejów 1944-1947. Warszawa: Wyd. Ministerstwa Obrony Narodowej, 1968.

Ginalski, Edmund. Od Żytomierza do Litomiěric. Zarys dziejów 15 pułku piechoty 1944-1947. Warszawa: Wyd. Ministerstwa Obrony Narodowej, 1972.

Ginalski, Edmund i Eugeniusz Wysokiński. Dziewiąta drezdeńska. Z dziejów 9 Drezdeńskiej Dywizji Piechoty (1944-1947). Warszawa: Wyd. Ministerstwa Obrony Narodowej, 1984.

Grzelak, Czesław, Henryk Stańczyk i Stanisław Zwoliński. Bez możliwości wyboru. Wojsko Polskie na froncie wschodnim 1943-1945. Warszawa: Bellona, 1993.

Исаев, Алексей. Берлин 45-го. Сражение в логове зверя. Москва: Эксмо, 2007.

Jaroniec, Paweł. „Obraz żołnierzy Armii Czerwonej we wspomnieniach kombatantów «ludowego» Wojska Polskiego na froncie wschodnim w latach 1943-1945 publikowanych w polskiej prasie codziennej w latach 70. XX wieku. Przyczynek do zagadnienia." Studia z Dziejów Wojskowości 5, (2016): 193-213.

Juchniewicz, Mieczysław. 36 Łużycki. Warszawa: Wyd. Ministerstwa Obrony Narodowej, 1975.

Juchniewicz, Mieczysław. Poczta polowa 52160. Z dziejów 35 pułku piechoty. Warszawa: Wyd. Ministerstwa Obrony Narodowej, 1963. 
Juchniewicz, Mieczysław. Śladami walk. Z dziejów 37 pułku piechoty. Warszawa: Wyd. Ministerstwa Obrony Narodowej, 1964.

Jurgielewicz, Waldemar. „Rozbudowa Ludowego Wojska Polskiego w II połowie 1944 r." Wojskowy Przegląd Historyczny 8, nr 3/4 (1963): 2-68.

Kaczmarek, Kazimierz. Czwarta pancerna. $Z$ dziejów czwartej brygady pancernej. Warszawa: Wyd. Ministerstwa Obrony Narodowej, 1970.

Kaczmarek, Kazimierz. Druga Armia Wojska Polskiego. Warszawa: Wyd. Ministerstwa Obrony Narodowej, 1978.

Kaczmarek, Kazimierz. „Operacja Łużycka 2 Armii WP” Cz. 1. Wojskowy Przegląd Historyczny 9, nr 1 (1964): 3-39.

Kaczmarek, Kazimierz. W bojach przez Łużyce: na drezdeńskim kierunku operacyjnym. Red. Emil Jadziak. Warszawa: Wyd. Ministerstwa Obrony Narodowej, 1965.

Kania, Leszek. „Sądy wojenne w Ludowym Wojsku Polskim (1943-1945).” Miscellanea Historico-Iuridica 14, z. 1 (2015): 233-252.

Kaseja, Michał. Ostatnie uderzenie. Warszawa: Wyd. Ministerstwa Obrony Narodowej, 1969.

Kaseja, Michał. Razem ze Świerczewskim. Warszawa: Wyd. Ministerstwa Obrony Narodowej, 1968.

Katroń, Władysław. „Udział 16 Dnowskiej Brygady Pancernej w operacji łużyckiej 2 Armii WP." Wojskowy Przeglad Historyczny 5, nr 3 (1960): 3-36.

Klibański, Marek. „Działania bojowe 2 Dywizji Artylerii w operacji łużyckiej 2 Armii WP." Wojskowy Przeglad Historyczny 6, nr 1 (1961): 3-64.

Koniew, Iwan. Notatki dowódcy frontu 1943-1945. Tłum. Piotr Marciniszyn i Czesław Waluk. Warszawa: Wyd. Ministerstwa Obrony Narodowej, 1986.

Kospath-Pawłowski, Edward. Wojsko Polskie na Wschodzie 1943-1945. Pruszków: Ofic. Wyd. „Ajax”, 1993.

Le Lissier, Tony. Żukow na linii Odry. Rozstrzygajaca bitwa na przedpolach Berlina. Tłum. Tomasz Szlagor. Wrocław: Wyd. Dolnośląskie, 2011.

Lubecki, Leon. Na południe od Berlina. Z walk 26 pp. Warszawa: Wyd. Ministerstwa Obrony Narodowej, 1960.

Лопуховский, Лев. Вяземская катастрофа 1941. Страшнейшая трагедия войHbl. Москва: Яуза-Каталог, 2019.

Nalepa, Edward. Oficerowie Armii Radzieckiej w Wojsku Polskim 1943-1968. Warszawa: Bellona, 1995.

Patelski, Mariusz. „Karol Świerczewski „Walter” - Komunista i generał.” Zeszyty Naukowe Uniwersytetu Opolskiego 32, z. 36 (1996): 73-82.

Roberts, Geoffrey. Generał Stalina. Życie Gieorgija Żukowa. Tłum. Janusz Ochab. Kraków: Wyd. „Znak”, 2014.

Różański, Piotr. „Powstanie, organizacja oraz szlak bojowy 2 Łużyckiej Dywizji Artylerii." Wojsko i Technika, listopad-grudzień, nr 6 spec. (2018): 68-79.

Rzepski, Stanisław. 8 Dywizja Piechoty. Z dziejów 8 Drezdeńskiej Dywizji Piechoty im. Bartosza Głowackiego. Warszawa: Wyd. Ministerstwa Obrony Narodowej, 1970.

Sankowski, Józef. „Działania 2 Armii Polskiej na rzeką Nysą.” Bellona 2, z. 3/4 (1946): $32-46$.

Stańczyk, Henryk i Stefan Zwoliński. Wojsko Berlinga i Żymierskiego 1943-1945. Warszawa: Ofic. Wyd. „Rytm”, 2015. 
Stąpor, Zdzisław. Berlin 1945. Warszawa: Bellona, 2015.

Tkaczew, Władysław. Organa Informacji Wojska Polskiego 1943-1956. Kontrwywiad wojskowy. Warszawa: Bellona, 2007.

Wadecka, Saturnina. Budziszyn - kwiecień 1945. Warszawa: Wyd. Ministerstwa Obrony Narodowej, 1970.

Wołoszyn, Włodzimierz. Pod Budziszynem i Dreznem. Z dziejów 30 pułku piechoty. Warszawa: Wyd. Ministerstwa Obrony Narodowej, 1963.

Portale internetowe

Pamyat Naroda. Dostęp styczeń 1, 2021. https://pamyat-naroda.ru/documents/

\section{STRESZCZENIE}

Leszek Kania, Zadanie bojowe 2 Armii WP w operacji łużyckiej w świetle źródeł rosyjskich i dotychczasowych ustaleń badaczy. Historia do poprawki

Artykuł przedstawia zadania 2 Armii Wojska Polskiego na drezdeńskim kierunku operacyjnym w operacji berlińskiej w drugiej połowie kwietnia 1945 r. na tle zadań innych związków operacyjnych Armii Czerwonej, które wchodziły w skład wojsk 1 Frontu Ukraińskiego dowodzonego przez marszałka Iwana Koniewa. W artykule poddano krytyce stan badań i dotychczasowe ustalenia historyków wojskowości, które mijały się z faktami. Podstawą wniosków mogą być przede wszystkim źródła w postaci dokumentów wytworzonych w czasie wojny przez dowództwa walczących wojsk. Po uwzględnieniu materiału źródłowego autor dokonał korekty wcześniejszych poglądów na temat zadania 2 Armii Wojska Polskiego na Łużycach w drugiej połowie kwietnia $1945 \mathrm{r}$. To stawia w zupełnie nowym świetle ocenę dowodzenia wojskami wchodzącymi w skład 1 Frontu Ukraińskiego na drezdeńskim kierunku operacyjnym. Zwłaszcza zaś przez dowódcę 2 Armii Wojska Polskiego, któremu niesłusznie przypisano doprowadzenie do chaosu i ciężkich strat w toku operacji łużyckiej.

Słowa kluczowe: Karol Świerczewski, Iwan Koniew, Budziszyn, 2 Armia WP, 1 Front Ukraiński, operacja łużycka, operacja berlińska

\section{SUMMARY}

\section{Leszek Kania, A Study concerning the Tasks of the 2nd Polish Army during the Red Army Advance on Dresden based on both Russian Sources and existing Research. History that needs to be revisited}

The article discusses the tasks of the 2nd Polish Army during their advance towards Dresden in the second half of April 1945 as part of the strategic offensive to capture Berlin. The tasks are contrasted with orders that were given to other Red Army units of the 1st Ukrainian Front commanded by Marshall Ivan Konev. The author, whose findings are primarily based on official documents that came from 
Red Army command headquarters, criticizes the state of research and the previous findings of military historians, which were based on incomplete facts. After considering these materials, the author has corrected previously held viewpoints regarding the tasks of the 2nd Polish Army in Lusatia during the second half of April 1945. This sheds new light on assessments of the leadership of the units involved in the 1st Ukrainian Front's advance on Dresden, especially by the commander of the 2nd Polish Army, who was unfairly credited with causing chaos and being responsible for the heavy losses suffered during the operation.

Keywords: Karol Świerczewski, Ivan Konev, Bautzen, 2nd Polish Army, 1st Ukrainian Front, Lusatian operation, Berlin operation

\section{АННОТАЦИЯ}

\section{Лешек Кан я, Боевая задача 2-й армии Войска Польского во время лужицкой операции в свете российских источников и существующих мнений исследователей. Поправки в историю}

В статье представлены задачи 2-й армии Войска Польского на дрезденском оперативном направлении в Берлинской операции во второй половине апреля 1945 г. на фоне задач других оперативных объединений Красной Армии, входивших в состав войск 1-го Украинского фронта под командованием маршала Ивана Конева. В статье критикуется состояние исследований и существующие на данный момент выводы военных историков, которые не совпадают с фактами. Основанием для умозаключений могут быть прежде всего источники в виде документов, составленных во время войны штабами боевых войск. Учитывая исходный материал, автор скорректировал прежние взгляды на задачу 2-й армии Войска Польского в Лужицкой зоне во второй половине апреля 1945 г. Это позволило совершенно по-новому взглянуть на оценку командования войсками, входящими в состав 1-го Украинского фронта на дрезденском оперативном направлении, особенно из-за командующего 2-й армией Войска Польского, которому ошибочно приписывали доведение ситуации до хаоса и большие потери в ходе лужицкой операции.

Ключевые слова: Кароль Сверчевский, Иван Конев, Баутцен, 2-я армия Войска Польского, 1-й Украинский фронт, лужицкая операция, берлинская операция 